NBER WORKING PAPER SERIES

\title{
INTERGENERATIONAL EFFECTS OF WELFARE REFORM: ADOLESCENT DELINQUENT AND RISKY BEHAVIORS
}

\author{
Dhaval M. Dave \\ Hope Corman \\ Ariel Kalil \\ Ofira Schwartz-Soicher \\ Nancy Reichman \\ Working Paper 25527 \\ http://www.nber.org/papers/w25527 \\ NATIONAL BUREAU OF ECONOMIC RESEARCH \\ 1050 Massachusetts Avenue \\ Cambridge, MA 02138 \\ February 2019, Revised July 2021
}

\begin{abstract}
Research reported in this publication was supported by the Eunice Kennedy Shriver National Institute of Child Health \& Human Development of the National Institutes of Health under Award Number R01HD086223 and by the Robert Wood Johnson Foundation through its support of the Child Health Institute of New Jersey at Robert Wood Johnson Medical School, Rutgers University (grants 67038 and 74260). The content is solely the responsibility of the authors and does not necessarily represent the official views of the National Institutes of Health or the Robert Wood Johnson Foundation. The authors are grateful to Elizabeth Lower-Basch for valuable input; Karen Conway, Jeff DeSimone, Daniel Grossman, Brady Horn, Brad Humphries, Joseph Sabia, Orgul Ozturk, and Nicholas Anthony Wright for helpful comments, to the staff at the University of Michigan's NADHAP for their data and technical help, and Michael Papotto for excellent research assistance. The views expressed herein are those of the authors and do not necessarily reflect the views of the National Bureau of Economic Research.
\end{abstract}

NBER working papers are circulated for discussion and comment purposes. They have not been peerreviewed or been subject to the review by the NBER Board of Directors that accompanies official NBER publications.

(C) 2019 by Dhaval M. Dave, Hope Corman, Ariel Kalil, Ofira Schwartz-Soicher, and Nancy Reichman. All rights reserved. Short sections of text, not to exceed two paragraphs, may be quoted without explicit permission provided that full credit, including $\odot$ notice, is given to the source. 
Intergenerational Effects of Welfare Reform: Adolescent Delinquent and Risky Behaviors Dhaval M. Dave, Hope Corman, Ariel Kalil, Ofira Schwartz-Soicher, and Nancy Reichman NBER Working Paper No. 25527

February 2019, Revised July 2021

JEL No. H53,I12,I31,I38

\section{ABSTRACT}

This study investigates effects of welfare reform in the U.S. on the next generation. Most previous studies of effects of welfare reform on adolescents focused on high-school dropout of girls or fertility; little is known about how welfare reform has affected teenage boys. We use a difference-in-difference-in-differences framework to identify gender-specific effects of welfare reform on salient adolescent behaviors (skipping school, fighting, damaging property, stealing, hurting others, smoking, alcohol, marijuana, other illicit drugs). Welfare reform led to increases in delinquent behaviors of boys as well as increases in substance use of boys and girls, with substantially larger effects for boys.

Dhaval M. Dave

Bentley University

Department of Economics

175 Forest Street, AAC 195

Waltham, MA 02452-4705

and IZA

and also NBER

ddave@bentley.edu

Hope Corman

Department of Economics

Rider University

2083 Lawrenceville Road

Lawrenceville, NJ 08648

and NBER

corman@ rider.edu

Ariel Kalil

Harris School of Public Policy

University of Chicago

1155 E. 60th Street

Chicago, IL 60637

a-kalil@uchicago.edu
Ofira Schwartz-Soicher

Princeton University

Donald Stokes Library

Princeton, US 08544

oschwart@princeton.edu

Nancy Reichman

Rutgers University

Robert Wood Johnson Medical School

Department of Pediatrics

Child Health Institute of New Jersey

89 French St., Room 3272

New Brunswick, NJ 08903

reichmne@rutgers.edu 
The 1996 U.S. Personal Responsibility and Work Opportunity Reconciliation Act (PRWORA) was a major policy shift that sought to dramatically reduce dependence of unmarried mothers on public assistance. The key strategy was to promote employment by imposing work requirements as a condition for receiving benefits in concert with a lifetime limit on receipt of cash assistance. The assumption was that labor force participation would break a culture of dependence (Katz, 2001), but there also were concerns that the reforms would contribute to existing hardships (Lichter \& Jayakody, 2002).

Another assumption behind the reforms was that a work-focused regime would not only improve behaviors of mothers, but that it would improve behaviors of the next generation and disrupt an intergenerational transmission of dependence. Studies found that PRWORA led to decreased high school dropout of girls (see Dave et al., 2012 for a review) and teen fertility (see Lopoo \& Raissian, 2012 for a review), at least in part through its "minor mother" requirements that mothers under 18 participate in education or training activities and live with a parent or guardian. Few other adolescent behavioral outcomes have been explored in the context of welfare reform and the studies on dropout focused on girls. ${ }^{1}$ Although welfare reform was primarily targeted to females, the second-generation effects could be substantial for boys. E.g., a recent study found that gender gaps in disciplinary problems, achievement test scores, and high school completion (all favoring girls) were larger in disadvantaged families than in more advantaged families (Autor et al., 2019), suggesting that changes in families' economic circumstances affect the behaviors of boys more than girls.

We address this gap by investigating gender-specific effects of welfare reform, which was implemented in the U.S. in the 1990s but is still in effect, on a range of behaviors of high

\footnotetext{
${ }^{1}$ Studies of teen fertility have also focused on girls, but that outcome does not cleanly reflect gender-specific behavior.
} 
school-aged youth. These include skipping school, getting into fights, damaging property, stealing, hurting others, and various types of substance use. These outcomes can occur within a relatively short time frame and represent early observable consequences of the reforms for the next generation in a particularly important period of development, when decisions can have long term consequences for future economic success and health (Steinberg, 2014).

\section{Background}

\section{Welfare reform in the United States}

In 1996, PRWORA ended entitlement to welfare benefits under Aid to Families with Dependent Children (AFDC) and replaced AFDC with Temporary Assistance for Needy Families (TANF) block grants to states. Key features of the legislation were time limits on cash assistance and work requirements as a condition for receiving benefits. States were granted considerable latitude in establishing eligibility and program rules subject to national guidelines that mandated work requirements and a 5-year lifetime limit on the receipt of cash assistance.

Reforms actually started taking place in the early 1990s with the expanded use of "welfare waivers" that allowed states to carry out experimental changes to their AFDC programs. Although not federally mandated, waivers were implemented in the majority of states by the time the federal PRWORA legislation was enacted in 1996. Many features of PRWORA, such as work requirements and time limits, were features of these earlier programs.

Major statewide waivers - defined in a 1997 report by the Council of Economic Advisors (CEA, 1997) as those that substantially altered the nature of AFDC with respect to work requirements and incentives, time limits, and family caps - were introduced in 29 states over a period of 53 months, and TANF was implemented in all states over a period of 17 months (Appendix Table 1). Considering both waivers and TANF, states reformed their welfare 
programs over a period of 64 months, from October 1992 through January 1998.

The reforms have had substantial impact. Average monthly family welfare caseloads in the U.S. declined by 78\% between 1994 to 2017 (ACF, 2018). Employment of low-skilled women increased by as much as $27 \%$ as a result of the reforms (Fang \& Keane, 2004; Ziliak, 2016). Welfare reform led to declines in women's substance use (Corman et al., 2013; Kaestner \& Tarlov, 2006) and crime (Corman et al., 2014) and increases in women's civic participation in the form of voting (Corman, Dave \& Reichman, 2017).

Empirical studies of effects of welfare reform on adolescents

As indicated earlier, welfare reform led to increases in high school completion of girls and decreases in teen fertility. Syntheses of findings from pre-PRWORA welfare experiments in specific geographic areas found mixed effects on suspension or expulsion from school and academic performance, but few evaluations included gender-specific effects (Gennetian et al., 2002, 2004; Grogger \& Karoly, 2005). Gennetian et al. (2002) summarized the limited genderspecific findings — on mother-reported school performance, grade repetition, special education, suspension/expulsion from school, school dropout, and childbearing. The only noteworthy gender difference was that certain waiver programs had no effects on grade repetition for girls but led to decreases in grade repetition for boys.

Two recent studies exploited differences in the full implementation of welfare reform across states and over time to identify causal effects on arrests for drug-related (Corman et al., 2017a) and non-drug-related (Corman et al., 2017b) crime among teens ages 15-17. The former found that welfare reform led to increases in drug-related arrests, with effects that appeared to be stronger for boys than for girls. The latter focused on crimes categorized as serious (violent offenses such as assault, rape, and murder, as well as serious property offenses such as burglary, 
possession of stolen property, and vandalism) and minor (e.g., disorderly conduct, curfew and loitering law violations) and found that welfare reform led to fewer arrests for minor crimes with similar estimates for boys and girls. However, effects on arrests could potentially reflect welfarereform-induced changes in reporting of teen crime (perhaps as a result of changes in maternal employment or supervision) that changed the probability of arrest rather than teens' behavioral responses. Also, arrest data only include crimes that result in arrests. For these reasons, it is important to focus on behavior rather than arrests. We know of no other studies of genderspecific effects of welfare reform in the U.S. on teen delinquent behaviors or substance use.

Overall, knowledge about potential gender-specific effects of welfare reform on teenage behaviors - other than high school dropout, an outcome targeted by PRWORA to minors who were mothers - is very limited. The very few existing studies suggest stronger effects for boys than girls-larger increases in drug-related arrests for boys than girls and decreases in grade repetition only for boys. Research on non-education-related outcomes such as delinquent behaviors or substance use is particularly rare, and only Corman et al. (2017 a \& b) considered the full implementation of welfare reform. We address this major gap by undertaking a comprehensive analysis of gender-specific effects of welfare reform in the U.S. on a range of salient adolescent behaviors. Delinquent behaviors in adolescence can be precursors to criminal careers (Loeber, Farrington \& Petechuk, 2013), and use of cigarettes, alcohol, and illicit drugs are illegal behaviors that also confer health risks.

\section{Expected effects}

Employment could increase household income, which could improve teens' behaviors. E.g., Akee et al., (2010) found that a positive income shock led to increases in parental supervision and lower levels of drug dealing and minor crimes among teenage children. 
However, maternal employment could lead to a net increase in constraints (e.g., if increases in income do not offset transportation and childcare expenses, or by decreasing time available for supervision), which could lead to undesirable effects on teens' behaviors. Moreover, welfare reform was a strong intervention designed to not only move women from welfare to work, but also to change the normative climate from a culture of dependence to one of personal responsibility, and it precluded welfare reliance as a long-term option for the next generation by time-limiting cash assistance. As such, it may have led teens (particularly girls) to focus more on school and community activities as investments in human and social capital. Reduced high school dropout of girls would also have reduced girls' time and opportunities for engaging in delinquent behaviors. ${ }^{2}$ Additionally, welfare reform may have led mothers to set a positive example for their children and be more engaged parents, which would be expected to improve their children's behaviors. However, welfare reform also could have adversely affected parenting quality or quantity, perhaps through increased stress and conflict within household, and ultimately lead to unfavorable teenage behaviors. E.g., Paxson and Waldfogel (2003) found suggestive evidence that early welfare reforms led to increased cases of child maltreatment.

Regarding potential gender differences, studies have shown that: (1) Factors that affect criminal behavior generally have less of an effect for females than for males (e.g., Levitt \& Lochner, 2001), suggesting that the effects of welfare reform on adolescent delinquent behaviors, if any, would be stronger for boys than girls. (2) Disruptive events have more adverse effects on teenage behaviors of boys than girls (e.g., Bertrand \& Pan, 2013; Kling et al., 2005), suggesting that effects would be stronger for boys, if welfare reform is experienced as a disruptive event. (3) Girls are more likely than boys to take care of younger siblings (East, Weisner \& Slonim, 2009)

\footnotetext{
${ }^{2}$ As noted earlier, PRWORA led to decreases in teen fertility, at least in part through its "minor mother" requirements. It is not clear a priori how a reduction in fertility would translate to delinquent behaviors.
} 
and there is some evidence that this type of caretaking increased in the aftermath of welfare reform (Hsueh \& Gennetian, 2011), suggesting that girls may have fewer opportunities than boys to engage in recreational behaviors as a result of welfare reform. (4) Girls are much more likely than boys to rely on welfare when they are adults; <15\% of adult TANF recipients in 2015 were male (ACF, 2016), suggesting that welfare reform would improve behaviors of girls, if youth are forward looking in this regard. (5) Girls are more subject than boys to potential maternal role modeling effects (Bussey \& Bandura, 1984; Perry \& Bussey, 1979), suggesting that welfare reform could have led to improved behaviors of girls through this potential channel.

Overall, theory and findings relevant to various possible mechanisms suggest that the effects of welfare reform on teenage behaviors would be the product of potentially competing forces, may differ depending on the specific behavioral outcome, and may differ by gender.

\section{Data}

We use restricted data from the $10^{\text {th }}$ and $12^{\text {th }}$ grade surveys of Monitoring the Future (MTF), an annual nationally-representative survey of high school students, for the years 1991 through 2006. ${ }^{3}$ We use 1991 as the starting point because that was the year the MTF began surveying $10^{\text {th }}$ graders and it also preceded welfare reform in all states. We use 2006 as the endpoint in order to allow all states to have fully implemented welfare reform and to avoid conflating our results with the effects of the Great Recession that began in the last quarter of 2007. The MTF is administered at over 400 public and private schools, providing representative samples of students in $8^{\text {th }}, 10^{\text {th }}$, and $12^{\text {th }}$ grades. Between 13,000 and 19,000 students are surveyed each year in each of the three grades. We limit our primary sample to high school

\footnotetext{
${ }^{3}$ More information about the MTF study design can be found at http://www.monitoringthefuture.org/purpose.html.
} 
students (grades 10 and 12) who are minors (<18 years old). ${ }^{4}$

MTF began in 1975 and was designed for the purpose of studying substance use, attitudes, and behaviors of youth, teens, and adults. It is one of two large federal surveys used to track adolescent drug use in the U.S. (SAMHSA, 2012). ${ }^{5}$ Questionnaires are administered in the schools rather so parents are never physically near the teen while he/she is completing them. Teens are assured that their responses are confidential and private, and the data collection protocol was designed to minimize underreporting of sensitive information.

The MTF allows us to have an observation period that envelops welfare reform; has large sample sizes overall; includes information on many relevant behaviors that can take place inside or outside of school; includes the mother's marital status and education, which are needed for our analyses; and asked teens about their own behaviors rather than relying on mothers' reports. ${ }^{6}$ Multiple "forms" of the survey are administered such that some questions are asked only of random subsamples of respondents. For the $10^{\text {th }}$ graders, there were 2 different forms from 1991 through 1996 and 4 different forms from 1997 onward. For the $12^{\text {th }}$ graders, there were 6 different forms. For this reason, sample sizes vary across behavioral outcomes.

In supplementary analyses to explore specific methodological issues, we use restricted data from the 1979 cohort of the National Longitudinal Survey of Youth 1979 (NLSY) linked with information on their children from the Child Self-Administered (CS) and Young Adult (YA) Self-Report surveys. ${ }^{7}$ The behavioral outcomes and sample sizes available in the NLSY are

\footnotetext{
${ }^{4}$ We exclude 18-year-olds given our focus on minors but confirmed that the findings were insensitive to that exclusion. All supplementary results not shown are available upon request.

${ }^{5}$ The other is the National Survey on Drug Use and Health (NSDUH), for which geographic indicators going back to the early 90s are not publicly available. Moreover, the NSDUH is limited in measures of teen behaviors, has a smaller teen sample than the MTF, and was administered in the household when parents might be present.

${ }^{6}$ Mothers may not always be aware of their teens' delinquent behaviors and substance use. The Youth Risk Behavior Survey has many of the same advantages as MTF but does not have information on maternal marital status or education, which are key for our methodology.

${ }^{7}$ The original NLSY sample consisted of $>12,000$ youth ages $14-22$ years old in 1979 . The self-administered CS
} 
much more limited than in the MTF.

\section{Measures}

\section{Outcomes}

\section{Delinquent Behaviors}

Skipping school. Students were asked how many school days they missed in the past 4 weeks due to "skipping" or "cutting." We coded them as skipping school if the answer was 1 or more.

Damaging property. Students were asked how often they damaged school property in the last 12 months. We coded them as damaging property if they answered once or more.

Involved in fights. Students were asked how often (ranging from never to 5+ times), in the past year, they had gotten into a serious fight in school or work. We coded this outcome as a "yes" if the student responded that he/she had been in a serious fight at least once.

Stealing. In two separate questions, students were asked how often in the past year they took something not belonging to them worth $<\$ 50$ or $>\$ 50$, respectively. We coded them as engaging in stealing if they answered "at least once" to either question.

Hurting someone. Students were asked how often they hurt someone badly (physically) in the past 12 months. We coded them as hurting someone if they responded once or more often.

\section{$\underline{\text { Substance Use }}$}

We consider four categories of substance use: marijuana, alcohol, other illicit drugs, and cigarettes. For each, students were asked how many times they engaged in the activity in the past 30 days. For illicit drugs other than marijuana/hashish, students were asked about types of drugs,

and YA surveys are administered to children of the women in the original sample. Beginning in 1988, the CS has been administered biannually to children ages 10+. Starting in 1994, the YA survey has been administered to children ages $15+$ and the CS (which has much more detailed data on youth behaviors) was administered only to children ages 10-14. In order to construct a sample as comparable as possible to that in our MTF analyses we focused on teens ages 15-17 in 1990-2006. 
which included substances without a doctor's prescription: LSD, other psychedelics, crack cocaine, other form of cocaine, amphetamines, barbiturates, tranquilizers, heroin, other narcotics, and inhalants. For each category of substance use, students were coded as engaging in the activity if they reported that they had done so (for other illicit drugs, any of the types listed) at least once. In addition, we combined all substances into a variable called any substance use, which is coded positive if the respondent reported using any of the four types of substances.

\section{Welfare reform}

Following the convention in the welfare reform literature (Blank, 2002), we exploit differences in the timing of both AFDC waivers and TANF implementation across states. For waivers, we consider whether, in a given month/year, a given state had a statewide AFDC waiver in place that substantially altered the nature of AFDC based on the CEA classification (1997). For TANF, we consider whether, in a given month/year, the state had implemented TANF postPRWORA. In most specifications, we include a single indicator for any welfare reform (AFDC waiver or TANF). In supplementary models, we use separate indicators for AFDC and TANF.

We matched the timing of each phase of welfare reform to the teens' surveys based on maternal state of residence and month/year of interview. A teen is considered exposed to welfare reform if the mother resided in a state in which welfare reform had been in effect for at least 12 months (i.e., welfare reform had been implemented at least 12 months before the month of interview). The 1-year lag addresses the retrospective nature of the outcomes, many of them capturing participation over the past year, and also allows for a lag between maternal exposure to welfare reform, maternal responses to welfare reform, and children's behavioral responses. ${ }^{8}$

\footnotetext{
${ }^{8}$ We also estimated models with the welfare reform indicator matched based on the month prior to the interview, making it contemporaneous with the start of the window of time referenced for substance use behaviors. If individuals are more likely to report behaviors that are recent, the contemporaneous treatment indicator is likely more salient.
} 


\section{Covariates}

Individual-level covariates in all analyses include the child's age, grade in school, and race/ethnicity (white, black, or other, with the last category including Hispanics). Mothers' marital status and education are used to define the target and comparison groups and education is controlled for as relevant (e.g., when comparing groups with mothers with at most a high school education, we control for maternal high school completion). State/year covariates include unemployment rate, poverty rate, personal income per capita, Earned Income Tax Credit (EITC) rate, refundable EITC, minimum wage, number of Medicaid beneficiaries, numbers of National School Breakfast and Lunch Program beneficiaries, and population.

\section{Methods}

$\underline{\text { Baseline difference-in-difference-in-differences }}$

Our main analyses are based on a quasi-experimental difference-in-difference-indifferences (DDD) design that exploits variation in the timing of welfare reform implementation across states in conjunction with comparisons across treatment and comparison groups. The following reduced-form baseline difference-in-differences (DD) specification directly relates changes in a teen's behaviors to their exposure to welfare reform, for the target group:

$$
\begin{aligned}
& \text { Dimst }_{\text {Target }}=\alpha_{1}+\Pi_{1}\left(\text { Welfare }_{\text {st }-12}\right)+X_{\text {imst }} \beta_{1}+V_{\text {mst }} \lambda_{1}+Z_{\text {st }} \theta_{1}+\text { State }_{\mathrm{s}} \Omega_{1}+\text { Time }_{t} \Psi_{1}+ \\
& \varepsilon_{\text {imst }}
\end{aligned}
$$

A given behavior ( $D_{\text {imst }}$ ), for the $i^{t h}$ child born to mother $m$ residing in state $s$ and

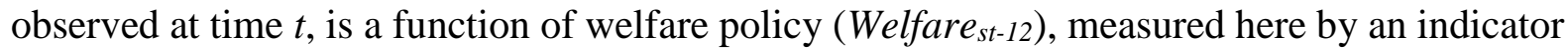
for whether a given state had in place a major AFDC waiver (prior to enacting TANF) or had implemented TANF for at least 12 months. As indicated earlier, we build in the 12-month lag

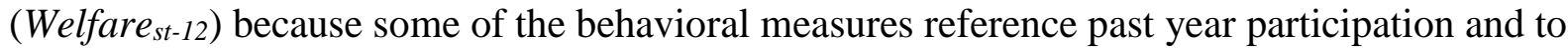


allow time for the implementation of welfare reform to affect maternal and youth behaviors. ${ }^{9}$ In alternate specifications, we use separate indicators for the two phases of welfare reform that capture whether the state had an AFDC waiver in place for at least 12 months and whether the state had implemented TANF for at least 12 months. We control for vectors of child characteristics $\left(X_{\mathrm{imst}}\right)$ and maternal characteristics $\left(V_{\mathrm{mst}}\right)$.

Models are estimated separately by the child's gender because, as discussed earlier, there are many reasons to expect that boys and girls would respond differently to the policy shift. We estimate all models using Ordinary Least Squares (linear probability models) and report standard errors that are adjusted for arbitrary correlation in the error term $\left(\varepsilon_{i m s t}\right)$ across and within individuals in a given state, and hence clustered at the state level. ${ }^{10}$

To account for potentially confounding policy shifts, we include a rich set of timevarying state factors $\left(Z_{\mathrm{st}}\right)$, detailed earlier and in table notes. Models further include State and Time $_{t}$ (month/year of interview) fixed effects, which control for time-invariant state heterogeneity, national trends, and seasonal variations in youth outcomes. Identification in the DD setup is based on differential timing across states in the implementation of welfare reform.

The population of interest is children born to all women at risk of relying on public assistance, not just children born to current or former welfare recipients. Traditionally, the welfare caseload has consisted primarily of low-educated unmarried mothers (Bitler \& Hoynes, 2010). This at-risk population is the target group of women for whom welfare policy would be expected to have the largest effects on employment, income, and other household conditions and potentially the largest behavioral effects, if any, on their children. While we control for a large

\footnotetext{
${ }^{9}$ We explore the timing of the effects more formally in an event study framework. We also tested a one-month lag in the welfare reform measures, which yielded very similar estimates and results.

${ }^{10}$ We confirmed that the estimates are not sensitive to estimation via logit or probit regression.
} 
set of time-varying state-level factors, the possibility of omitted variables remains. We address this by considering a comparison group - individuals similar in many ways to the target group but unlikely to be affected by welfare reform - and estimating a similar DD specification for this "control" group:

$$
\begin{aligned}
& \left.D_{\text {imst }}\right|_{\text {Comparison }}=\alpha_{2}+\Pi_{2}\left(\text { Welfare }_{\mathrm{st}-12}\right)+\mathrm{X}_{\text {imst }} \beta_{2}+\mathrm{V}_{\mathrm{mst}} \lambda_{2}+\mathrm{Z}_{\mathrm{st}} \theta_{2}+\text { State }_{\mathrm{s}} \Omega_{2}+\text { Time }_{\mathrm{t}} \Psi_{2} \\
& +\eta_{\text {imst }}
\end{aligned}
$$

Since the comparison group is not at risk of relying on public assistance, outcomes for these individuals should not be affected by welfare reform. Thus, the coefficient $\Pi_{2}$ in Eq. 2 should be zero. If it is not zero, the "effects" for the comparison group would be capturing nonwelfare policy-related trends in teen behaviors. It can be subtracted from the corresponding estimate $\left(\Pi_{1}\right)$ in Eq. 1 to derive the causal impact of welfare reform on behaviors, accounting for the omitted factors. This difference $\left(\Pi_{1}-\Pi_{2}\right)$ is the unrestricted DDD estimate, allowing all parameters in Eqs. 1 and 2 to differ between the target and comparison groups.

There are efficiency gains in estimating the following (combined) specification. ${ }^{11}$

$$
D_{\text {imst }}=\alpha_{3}+\Pi_{3}\left(\text { Welfare }_{\mathrm{st}-12} * \text { Target }_{\mathrm{mst}}\right)+\Pi_{4} \text { Welfare }_{\mathrm{st}-12}+\mathrm{X}_{\mathrm{imst}} \beta_{3}+\mathrm{V}_{\mathrm{mst}} \lambda_{3}+\mathrm{Z}_{\mathrm{st}} \theta_{3}+
$$

State $_{\mathrm{s}} \Omega_{3}+$ Time $_{\mathrm{t}} \Psi_{3}+\mu_{\mathrm{imst}}$

Target $_{m s t}$ represents a dichotomous indicator equal to 1 if the teen is in the target group (had a low-educated unmarried mother and thus was at risk of being on welfare) and 0 if he/she is in the comparison group (had a mother who is not at risk of being on welfare; defined below). The

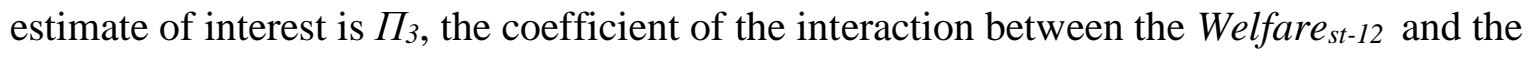
Target $_{\mathrm{mst}}$ group indicators, which represents the reduced-form effect of exposure to welfare

\footnotetext{
${ }^{11}$ The unrestricted DDD effect is equivalent to estimating Eq. 3 with interactions between the Target indicator and all covariates and fixed effects. We focus on restricted DDD estimates (Eq. 3) but also report the unrestricted DDD estimates that net out the DD effect for the comparison group from that for the target group.
} 
reform on the teen's behavior operating through any and all reinforcing and/or offsetting channels. $^{12}$

In these models, the error terms $\left(\mu_{i m s t}\right)$ for a given individual $i$ are likely to be correlated across the various outcomes since behaviors tend to be clustered within individuals. Accounting for cross-equation correlation across outcomes can increase statistical power and improve the efficiency of estimates. Thus, in some specifications, we transform the outcome variables into standard normal deviates $[(\mathrm{Y}-$ mean $) /$ standard deviation] and estimate the effects of welfare reform on youth behaviors using a seemingly unrelated regression (SUR) framework, allowing us to test joint hypotheses across equations. These estimates are evaluated as changes in standard normal deviations of the dependent variable, and we test whether the average estimate across models is statistically different from zero. Additionally, following Finkelstein et al. (2012), we compute and report the average standardized treatment effect across all outcomes.

$$
\text { (4) } \quad \sum_{j \in J} \frac{1}{J} \frac{\pi_{3 j}}{\sigma_{j}}
$$

In Eq. $4, \Pi_{3 j}$ represents the estimated DDD effect (based on Eq. 3) for a given outcome $j$ and $\sigma_{j}$ represents the standard deviation of outcome $j$ in the comparison group. We report the standard errors for the standardized effect accounting for the covariance in the estimates across outcomes and individuals. In addition to providing a convenient metric for summarizing findings across related outcomes in a standardized manner and making it straightforward to compare effects across gender and model specifications, both the SUR estimates and the standardized treatment effects have the added advantage of bypassing issues related to multiple comparisons and testing.

\footnotetext{
${ }^{12}$ A potential concern is that small state-level cell sizes could lead to biased estimates (Maclean, Trello-Trillo \& Webber, 2019). Average cell sizes for most outcomes are $>50$ and are consistently large for substance use outcomes. For delinquent behaviors other than skipping school, there are some small cells, which somewhat limit strong inferences vis-à-vis these outcomes. Our restricted data use agreement does not allow us to report specific cell sizes.
} 


\section{Assessing validity of DDD}

The key assumption necessary for the DDD estimate to represent an unbiased causal effect is that in the absence of welfare reform, unobserved time-varying state factors would affect the target and comparison groups similarly. We follow the literature by utilizing a target group of unmarried mothers with at most a high school education and a comparison group of similarly low-educated married mothers. ${ }^{13}$ As marriage generally precludes eligibility for cash assistance, low-educated mothers who are married are at much lower risk of welfare receipt than those who are unmarried and thus much less likely to be affected by welfare reform. ${ }^{14}$

The validity of this approach depends on welfare reform being unrelated to unobserved state-level factors that are associated with the outcomes, and similar trends in outcomes for the target and comparison groups before the implementation of welfare reform ("parallel trends" assumption). We assess the importance of unobserved time-varying state-specific factors and pre-welfare reform trends by adding 1-, 2-, and 3-year lags of the state's unemployment rate, poverty rate, personal income per capita, and welfare caseloads to the baseline model. ${ }^{15}$ This specification addresses the possibility that the timing of welfare reform implementation was dependent on, and thus endogenous to, the state's economic conditions and welfare history. We further include state-specific linear trends, which allow all states (including early- and late-

\footnotetext{
${ }^{13}$ The factors used to define the target group (marital status, education) are subsumed in the vector of controls for maternal characteristics (vector $V$ in Eq. 1), so a separate indicator differentiating the target and comparison groups is not needed.

${ }^{14}$ From the 2014 NSDUH, $\sim 14 \%$ of unmarried mothers with at most a high school education received "welfare," compared to only $\sim 2 \%$ of similarly educated married mothers. The NSDUH does not distinguish between welfare/cash, childcare, and job placement assistance, so some of the $2 \%$ likely reflects non-cash assistance. ${ }^{15}$ The lagged economic indicators are in addition to the contemporaneous measure of the state's economy included in the vector $\mathrm{Z}$. We do not control for contemporaneous welfare caseloads as those would be endogenous. The lagged measures of welfare caseloads help account for the possibility that the state-specific timing of welfare reform implementation was a function of the state's previous levels and trends in caseloads. However, given the high degree of correlation in a state's welfare population over time, the estimates from these models are only suggestive of the sensitivity of our estimates to selection on observed state-specific factors. We note that our estimates are not sensitive to these controls or to excluding the state-level controls (Z).
} 
reform states) to have differential systematic trends over the entire sample period. Finally, we expand the baseline DDD specification into an event study framework, which decomposes the policy effects into leads and lags and allows us to more formally identify significant differential trends between the target and comparison groups prior to policy implementation.

The validity of our approach also depends on the sample composition being unrelated to welfare reform. First, there may be selective composition with respect to classifying a mother as high- or low-educated (which determines classification into target or comparison group), as previous research found that adult women's educational enrollment was affected by welfare reform (Dave, Corman \& Reichman, 2012). We are less concerned about this type of bias with respect to marital status (which also determines classification into target and comparison group), as prior research has generally found weak to no effects of welfare reform on marriage (Ziliak, 2016). Using the MTF, we found that neither of these characteristics changed significantly or systematically over the sample period. We also used longitudinal data from the NLSY to more directly explore this issue. The results from these analyses suggest that compositional changes in completed education and marital status would not bias our estimates. ${ }^{16}$ Second, mothers' migration to more welfare-friendly states after implementation is another potential source of sample selection. Allard \& Danziger (2000) found that migration was not systematically related to welfare generosity, and in the NLSY only $4 \%$ of mothers with a high school education or less

\footnotetext{
${ }^{16}$ We compared estimates from models that defined the target and comparison groups based on maternal characteristics at the time of the survey when the youth outcomes were measured (as in all MTF analyses) to those from models that redefined the target and comparison groups using baseline maternal characteristics, with baseline being the year that the child entered the NLSY CS and YA (i.e., a mother is assigned to the target or comparison group during the first survey year when we observe the child and that assignment is fixed over the sample period, regardless of any changes in her marital status or educational attainment). The two specifications produced similar results. Sample sizes and availability of data fields allowed us to conduct these analyses for only two outcomesany substance use and hurt someone.
} 
and children aged 10-17 moved from one state to another between 1990 and $2006 .{ }^{17}$ Thus, interstate migration does not appear to be an important source of potential bias in our study. Third, since the MTF is a school-based sample and welfare reform led to decreased high school dropout (of girls), welfare reform may have affected the composition of the MTF sample. We address this issue by conducting auxiliary analyses that only include students younger than the legal dropout age.

\section{$\underline{\text { Alternate identification and fixed effects }}$}

We assess the robustness of the estimated effects of welfare reform to alternate comparison groups and by exploiting the MTF data to control for fixed effects at narrower levels than state of residence. First, we use an alternative comparison group that also has been established in the welfare reform literature-higher-educated unmarried mothers (specifically, unmarried mothers with more than a high school education). Second, in alternate specifications we control for time-invariant school-specific unobserved characteristics by adding school fixed effects. ${ }^{18}$ Since the policy variation is at the state level, we do not expect school-specific unobserved characteristics to introduce bias. However, accounting for heterogeneity across schools can reduce sampling variance and affect standard errors. Robustness of the estimates to adding school fixed effects also provides an indirect check on any systematic compositional selection issues with the school-based sampling in the MTF.

We also present estimates from a more flexible event study specification, which decomposes the timing of the policy effects into leads and lags and allows us to gauge (and

\footnotetext{
17 This small percentage represents an upper bound estimate of program-induced migration, since not all mothers moved for that purpose and some moves took place entirely before or after any policy changes.

${ }^{18}$ The school fixed effects are in lieu of state fixed effects, as the nesting of school districts within states accounts for unobserved factors at higher levels of geography. Controlling for county fixed effects in lieu of school fixed effects had no material effects on our estimates.
} 
partly adjust for) differential pre-policy trends between the treatment and comparison groups and assess lagged policy responses in the behavioral outcomes.

As a placebo check, we estimate the effects of welfare reform on the children of married college-educated mothers. We would not expect any statistically or substantively significant effects of welfare reform for this group, and significant effects would in fact point to spurious time-varying state trends.

\section{Results}

The means for the behavioral outcomes at baseline (survey years 1991 and 1992, before any welfare reform was implemented) are presented in Table $1 .{ }^{19}$ Means for the target group (children with unmarried mothers who had at most a high school education) are in the first and fourth columns, for boys and girls, respectively. Corresponding means are presented for both the main comparison group (A; children with similarly low-educated married mothers) and alternate comparison group (B; children with unmarried mothers with more than a high school education). The means were generally similar across the target and comparison groups. Boys were more likely than girls to engage in each type of delinquent behavior-damaging property, fighting, stealing, and hurting someone. Boys in the target group were more likely than boys in Comparison Group A to engage in delinquent behavior in three of the five categories, but less likely in the other two. Boys in Comparison Group B were more likely to engage in delinquent behavior than boys in the target group in four of the five delinquency categories. Substance use was fairly prevalent among youth in both the target and comparison groups, with participation ranging from $9-10 \%$ (other illicit drugs) to $~ 50 \%$ (alcohol) among boys and $\sim 10 \%$ (illicit drugs)

\footnotetext{
${ }^{19}$ The MTF surveys are fielded in school during the spring of each year. Thus, the 1992 MTF predates implementation of welfare reform in every state (see Appendix Table 1). Means for all outcomes and sample characteristics over the entire analysis period (1991-2006) are presented in Appendix Table 2. Sampling weights were used to generate all summary statistics.
} 
to $\sim 42 \%$ (alcohol) among girls. Overall, differences in substance use between the target and comparison groups and by gender were minimal.

We present baseline DDD estimates from Eq. 3 in Tables 2 and 3 for delinquent behaviors and substance use, respectively, by gender. The DDD coefficient of interest, $\Pi_{3}$, is reported. ${ }^{20}$ Welfare reform was associated with increases in delinquent behaviors, with larger effects for boys than girls (Table 2). Boys exposed to welfare reform were more likely to skip school (2.1 percentage points), damage property (4.1 pp), and be involved in a fight (6 pp) than those not exposed to welfare reform. These effect sizes translate into 7-21\% increases relative to the baseline means for the target group. We find non-negligible effect magnitudes for stealing and hurting someone (8-11\%) in the same direction, although the estimates are imprecise. For girls, we find a marginally significant effect only for skipping school (an increase of $1.7 \mathrm{pp}$, or $7 \%$ ); estimated effects on the other delinquent behaviors are close to zero and negative for two of the four outcomes. The differences between boys and girls are significantly different at the $10 \%$ level or better for damaging property and fighting. Welfare reform led to an increase in any substance use for both boys and girls, with increases in marijuana use and smoking for both genders and no changes in alcohol consumption; the one significant difference across gender was that boys were significantly more likely to use other illicit drugs, but girls were not.

Appendix Tables 3 and 4 present the component DD estimates, based on Eqs. 1 and 2, separately for the target and comparison groups, and the unrestricted DDD estimates that net out the DD effect for the comparison group from the DD effect for the target group. These estimates are largely similar to those in Tables 2 and 3. The DD effects for the target group indicate that

\footnotetext{
${ }^{20}$ We present unweighted estimates for all regression analyses. Estimates from regressions using sample weights are highly similar to those presented, but standard errors are slightly larger in the weighted regression models, which is to be expected. In the absence of endogenous sampling, unweighted estimates are consistent and more precise than weighted estimates (Solon, Haider \& Wooldridge 2015).
} 
welfare reform generally led to increases in delinquent behaviors and substance use for boys but not girls. Effects for the comparison groups are largely close to zero or suggest opposite decreasing trends. After subtracting out the effects for the comparison group, the unrestricted DDD estimates (which are equivalent to a fully-interacted specification) remain robust and continue to indicate that welfare reform adversely affected risky behaviors among boys, with much smaller or no effects among girls. However, standard errors are inflated in those models and we lose some statistical power. ${ }^{21}$

Appendix Table 5 reports estimates that decompose the composite effect of welfare reform into AFDC waivers and TANF implementation and addresses the concern that an idealworld estimate of treatment effects would include states that never adopted welfare reform, which is not possible. ${ }^{22}$ The third "D" in our models incorporates women who would not be impacted by a shift in welfare policies, who partly serve as 'never adopters' in this context, and differencing out their trends partly alleviates this concern. In addition, we find largely similar effects for each phase of welfare reform and are not able to reject the null that the effects of AFDC waivers and TANF are equal for any outcome or model. ${ }^{23}$

Our results are robust to several model extensions, all of which should be compared to

\footnotetext{
${ }^{21}$ Since we lose some statistical power in the fully-interacted DDD, we also estimated intermediate specifications that alternately interacted the covariates, state fixed effects, and period (year/month) fixed effects with the target group to ensure that our results are not confounded by failing to model differential effects across each of these dimensions. These estimates are very similar to those reported in Tables 2 and 3.

${ }^{22}$ The treatment effect in a standard DD is a weighted average of all possible 2-group and 2-period DD estimators (Goodman-Bacon, 2018). Generally, the main treatment effect would be identified by comparing: (1) early- and lateadopting states with never-adopting states as controls; (2) early-adopting states with late-adopting states as controls; and (3) late-adopting states with early adopting states as controls. For welfare reform, every state is an 'ever adopter,' so identification is driven by (2) and (3) which compare early and late adopters. If there are heterogeneous treatment effects over time, then using early-adopting states as controls for later-adopting states when the lateradopting states are implementing welfare reform may underestimate the treatment effects.

${ }^{23}$ Since the concern regarding the early adopters being possibly an inappropriate counterfactual for the later adopters arises when the treatment effect varies dynamically, we note that our event study analyses (discussed later) do not show any strong dynamic patterns such that the treatment effects get larger over time. This may be why we find similar effects for the early-adopting states (AFDC waivers) and the later adopters (TANF).
} 
those in Tables 2 and 3, both in terms of patterns (across outcomes and gender) and effect sizes. In Appendix Table 6, we control for lagged state-level economic conditions and welfare caseloads to address the potential endogeneity of the timing of welfare reform, which may reflect the state's recent economy and welfare caseloads. In Appendix Table 7, we control for statespecific trends and assess the sensitivity of the estimates to systematically (linearly) time-varying state unobserved characteristics and differential trends across states. ${ }^{24}$ In Appendix Table 8, we presents estimates that adjust for time-invariant school-specific heterogeneity by including school fixed effects. Finally, in Appendix Table 9, we present DDD estimates based on the alternate comparison group (unmarried mothers with more than a high school education). ${ }^{25}$

Table 4 presents estimates of the standardized treatment effects (following Finkelstein et al. 2012) and from a seemingly unrelated regression (SUR) framework that accounts for crossequation correlation across outcomes. For convenience, we focus on the DDD estimates derived from our baseline model that includes state covariates and state and time fixed effects, although the results are robust to the various alternative model specifications. The top panel reports the mean standardized treatment effects (MSTEs) across different sets of outcomes. For delinquent behaviors, welfare reform is associated with a statistically significant 0.08 standard deviation increase for boys but no statistically or substantively significant effect for girls, and we can reject the null of no gender differences. For marijuana, alcohol, smoking, and other illicit drugs, the standardized effects point to a welfare reform-induced increase in substance use for both boys and girls, with a stronger effect for boys (0.06 standard deviation vs. 0.04 for girls). Across all

\footnotetext{
${ }^{24}$ In the presence of a trend break and dynamic treatment effects, these trend controls could also absorb some of the treatment effect. Our event study analyses do not uncover strong dynamic patterns in the treatment effect, which may explain why the DDD effects are generally similar with and without state trend controls.

${ }^{25} \mathrm{We}$ also considered whether controlling for Medicaid enrollment biased our estimates, since some Medicaid policies were a result of welfare reform. Excluding it did not substantively or significantly change the estimates.
} 
behaviors, we again find evidence that welfare reform led to significantly worse behaviors and that the overall effect is substantially and significantly more negative for boys than for girls (0.072 vs. 0.025 standard deviation). The bottom panel presents the average DDD estimates from the cross-equation SUR framework, which maximizes statistical power and accounts for correlated errors across the outcomes. The patterns and magnitudes are highly similar to the corresponding MTSEs. ${ }^{26}$

In Tables 5 and 6, we parse out the timing of the effects of welfare reform by estimating an event study. Specifically, we define windows of time with respect to welfare reform implementation (month/year of implementation in each state) capturing pre-policy leads $(5+, 4$, 3 , and 2 years prior to implementation) ${ }^{27}$ and post-policy lags (within $1,2,3$, and $4+$ years postimplementation), with 1 year prior to implementation as the reference category. For brevity, only the DDD interactions between these timing indicators and the target group are reported. For boys, the lead effects are jointly insignificant (Table 5), suggesting no differential trends between the target and comparison groups prior to welfare reform. ${ }^{28}$ Significant welfare reform-associated increases in unfavorable behaviors are confined to periods after welfare reform was already in effect, and the strongest effects (particularly for substance use) appear 2-3 years post

\footnotetext{
${ }^{26}$ The difference in the effects for boys and girls is statistically significant at the $1 \%$ level for the set of all behaviors and for the set of delinquent behaviors. The difference is not statistically significant for the set of substance use outcomes, though this is driven primarily by marijuana and cigarette use. Girls are significantly less likely than boys to use other illicit drugs as a result of exposure to welfare reform (as shown in Table 3).

${ }^{27} \mathrm{We}$ are somewhat limited in the number of observations prior to welfare reform, since the MTF for $8^{\text {th }}$ and $10^{\text {th }}$ graders began in 1991. Not having a longer pre-period is not that consequential, however, because only 5 states (NJ, CA, OR, UT, MI) implemented welfare reform in late 1992 or early 1993 (MTF surveys are conducted in the spring), allowing us 3 pre-policy years $(1990,1991,1992)$ for these states, and another 3 states (IL, IA, GA) implemented welfare reform in late 1993 or early 1994, allowing for 4 policy leads. All other states implemented welfare reform in late 1994 or after, allowing for 5+ leading years. Thus, the full set of leads for $5+$ years were available for 43 states, for $4+$ years were available for 46 states, and for 3 years or less were available for all states. ${ }^{28}$ The only significant lead indicators are for the open-ended category (5+ years pre-policy), which essentially captures a sub-sample of states that implemented welfare reform in 1996 or later (generally, states that had not implemented waivers). While such timing analyses are common in the applied DD literature, they should be viewed as suggestive given recent evidence that lags and leads in event study-type models with heterogeneous treatment effects may spuriously reflect treatment effects from other periods (Goodman-Bacon, 2018; Abraham \& Sun, 2018).
} 
implementation. Given that some of the hypothesized mechanisms are indirect, driven first through changes in maternal behaviors, a lag in the policy response is plausible. For girls, the lead effects are all statistically insignificant and there is less evidence of lagged effects (Table 6). We find a marginally significant adverse effect only with respect to substance use, and, similar to the pattern for boys, there is some evidence of a lagged policy response, with stronger effects materializing 2-3 years post welfare reform. Overall, the event study results indicate little systematic evidence of differential pre-trends for boys or girls, more evidence of increases in delinquent behaviors post-welfare reform for boys than for girls, evidence of a welfare reformassociated increase in substance use for both genders with larger responses for boys, and when effects are apparent some evidence of a lagged policy-response with strongest effects taking place 2-3 years post-reform.

Table 7 presents estimated effects of welfare reform on the children of married collegeeducated mothers as a placebo check. These are DD estimates since no comparison group is utilized. Across all sets of outcomes, the average and standardized effects of welfare reform are statistically insignificant and the size of the standardized DD effect is small and close to zero.

To assess compositional selection due to high school dropout in the MTF data, we estimated models that excluded teens above the compulsory education age requirement in the relevant state/year, ${ }^{29}$ resulting in a sample size reduction of about $40 \%$. Results from these regressions were very similar to those for the full sample.

The DDD estimates presented to this point support a causal interpretation, particularly for substance use, given the numerous validity checks and robustness across specifications. As discussed earlier, the effects are plausibly driven by a number of different mechanisms, many of

\footnotetext{
${ }^{29}$ From the Education Commission of the States' Clearinghouse Notes, "Compulsory School Age Requirements," March 1992, March 1994, March 1997, and 2005, and http://nces.ed.gov/programs/digest/d04/tables/dt04_148.asp
} 
which are not observed or are imperfectly measured in the MTF, a school-based sample focusing on the students with few questions about their parents. In Appendix Table 10, we provide a very preliminary analysis of some of the hypothesized pathways. As mediators, we consider measures we can observe (albeit crudely) in the MTF, which are related to maternal employment, the teen's unsupervised time at home after school, and the teen's employment. The top row shows the average DDD estimates (from Table 4) without controlling for any of the mediators. The next row adds broad measures whether the teen engaged in any paid work after school, whether the teen was home alone for 4+ hours each day after school, and whether the teen's mother was employed. The last row incorporates more refined measures of working after school and being home alone after school- the number of hours for each. Comparing the average effects with and without the mediators, we find that $\sim 14-21 \%$ of the overall effects for boys and girls across the four substance use outcomes may be explained by the mediating factors considered, but that the mediators explain little of the observed effects for the other sets of outcomes. ${ }^{30}$

\section{Conclusion}

This study investigated gender-specific effects of welfare reform in the U.S. in the 1990s, which substantially reduced the cash assistance safety net for poor families, on delinquent behaviors and substance use of adolescent children. Most previous studies of effects of the full rollout of welfare reform in the U.S. on adolescents focused on high school dropout (of girls) or fertility; few considered outcomes for boys. Findings from specific pre-PRWORA experiments

\footnotetext{
${ }^{30}$ These exploratory results broadly suggest that welfare reform-induced decreases in supervision and/or increases in income from maternal or teen employment may have outweighed any welfare reform-induced increases in time constraints from teen employment or increases in normative behavior from maternal or teen employment in affecting teen substance use. However, Angrist \& Pischke (2008) caution against including mediators directly in models this way, as those factors are endogenous. We also estimated models with the potentially mediating variables as outcomes. Consistent with the prior literature, welfare reform was positively associated with maternal employment. It was also associated with the number of hours the child worked for pay after school and number of hours the child was home alone after school, but only significantly so for boys.
} 
suggest that welfare led to less grade repetition among boys, but that outcome could reflect either better academic performance or less maternal engagement. Corman et al. (2017a) found that welfare reform led to increases in drug-related arrests of teens and that the effects were stronger for boys than for girls, while Corman et al (2017b) found that welfare reform increased boys' arrests for minor crimes. However, arrests do not necessarily reflect underlying behavior. Thus, although past research has found some favorable effects of welfare reform on behaviors of adolescent girls (reduced dropout and fertility) that appeared to operate largely through specific policies targeted at minors who were mothers, little is known about behavioral effects of welfare reform for girls more broadly and virtually nothing is known about the potential effects—or even the direction of effects - for boys. This study addressed this important gap.

Welfare reform led to a significant increase in delinquent behaviors (skipping school, damaging property, fighting, stealing, hurting others) of boys, with an average DDD effect of .08 standard deviations. ${ }^{31}$ There were no systematic effects of welfare reform on these behaviors for girls other than a small increase in skipping school. Welfare reform led to increases in any substance use (marijuana, alcohol, cigarettes, other illicit drugs), with a larger average effect for boys than girls ( .06 versus $\sim .04$ standard deviations). As the median age of initiation is 16-17 years for-ever users of cigarettes and marijuana and 18 years for ever-users of other illicit drugs (from 2014 NSDUH), these estimates likely capture this initiation margin.

Overall, we found no evidence of favorable effects of welfare reform on youth behaviors, but considerable evidence of unfavorable effects that were generally much larger for boys than girls. Of the various hypothesized mechanisms laid out earlier, that most consistent with our gender findings is disruptive events taking more of a toll on boys, perhaps through differential

\footnotetext{
${ }^{31}$ The issue of some small cell sizes for delinquent behaviors other than skipping school is somewhat of a limitation.
} 
responses to welfare reform-associated maternal stress/anxiety, conflict between parents and children, or parental disengagement. This scenario is consistent with previous findings of gender differences in non-cognitive returns to parental inputs such as time, attention, and emotional connectedness during adolescence; e.g., Bertand \& Pan (2013) found that boys' likelihood of "acting out" was greatly reduced when they received higher quality and quantity of parental inputs, while the associations were much weaker for girls. Recent findings from experimental interventions that reduced youth crime and increased school engagement of disadvantaged boys in Chicago by shaping their decision making (e.g., getting them to take time and consider whether their impulses were appropriate) underscore that vulnerable boys can be responsive to structure and guidance (Heller et al., 2017). The stronger effects for boys than girls could also reflect differential maturity or impulsivity of boys and girls at the same ages or, possibly, differential effects of welfare-reform-induced changes in household composition, place of residence, or peer groups. Finally, it is possible that other hypothesized mechanisms buffered the effects for girls (e.g., assuming more responsibility for housework or childcare, internalizing the new reality that welfare is not a long-term option, or responding to positive maternal role modeling). Unfortunately, we were able to explore only a limited and crude set of mechanisms.

In summary, the findings from this study suggest that while welfare reform had many favorable effects on women's employment, crime, substance use, and other behaviors and teenage girls' high school dropout and fertility, the intergenerational effects on delinquent behaviors and substance use were not favorable, particularly for boys. As such, the gains of welfare reform may have come at a cost to the next generation, particularly to boys who have been falling behind girls in terms of high school completion for decades (Murnane 2013). More generally, the results underscore the importance of exploring the effects of policies, particularly 
those implemented on a large scale and currently in effect, on the next generation and

considering potential differential effects by gender.

\section{References}

Abraham, S., \& Sun, L., 2018. Estimating Dynamic Treatment Effects in Event Studies with Heterogeneous Treatment Effects. Working Paper. Available at: https://papers.ssrn.com/sol3/papers.cfm?abstract_id=3158747.

Administration for Child and Families, 2016. Characteristics and Financial Circumstances of TANF Recipients, Fiscal Year 2015. Accessed on 11/16/18 from: https://www.acf.hhs.gov/sites/default/files/ofa/characteristics_and_financial_circumstanc es_of_tanf_recipients.pdf.

Administration for Children and Families, U.S. Department of Health and Human Services. 2018. Compiled by authors from annual caseload reports. Retrieved on August 26, 2018 from: https://www.acf.hhs.gov/ofa/programs/tanf/data-reports

Akee, R., Copeland, W.E., Keeler, G., Angold, A., \& Costello, E.J., 2010. Parents' Incomes and Children's Outcomes: A Quasi-Experiment Using Transfer Payments from Casino Profits. American Economic Journal: Applied Economics, 2 (1), 86-115.

Allard SW, Danziger S. 2000. Welfare Magnets: Myth or Reality? The Journal of Politics 62 (2), 350-368.

Angrist J.D., \& Pischke J-S. Mostly Harmless Econometrics: An Empiricist's Companion. Princeton University Press: New Jersey; 2008.

Autor, D., Figlio, D., Krzysztof, K, Roth, J., \& Wasserman, M., 2019. Family Disadvantage and the Gender Gap in Behavioral and Educational Outcomes. American Economic Journal: Applied Economics, 11 (3), 338-381.

Bertrand, M., \& Pan, J., 2013. The Trouble with Boys: Social Influences and the Gender Gap in Disruptive Behavior. American Economic Journal: Applied Economics, 5 (1), 32-64.

Bitler, M.P., \& Hoynes, H.W., 2010. The State of the Social Safety Net in the Post-Welfare Reform Era." Brookings Papers on Economic Activity 2, 71-127.

Blank, R.M., 2002. Evaluating Welfare Reform in the United States (No. w8983). National Bureau of Economic Research.

Bussey, K., \& Bandura, A., 1984. Influence of Gender Constancy and Social Power on Sexlinked Modeling. Journal of Personality and Social Psychology, 47(6), 1292-1302.

Corman, H., Dave, D., Kalil, A., \& Reichman, N.E., 2017a. Effects of Maternal Work Incentives on Teen Drug Arrests. Advances in Health Economics and Health Services Research. 26. Emerald Group Publishing. In press.

Corman, H., Dave, D., Kalil, A., \& Reichman, N.E., 2017b. Effects of Maternal Work Incentives on Youth Crime. Labour Economics, 49, 128-144.

Corman, H., Dave, D.M., \& Reichman, N.E., 2017. Effects of Welfare Reform on Women's Voting Participation. Economic Inquiry, 55 (3), 1430-1451.

Corman, H., Dave, D.M., \& Reichman, N.E., 2014. Effects of Welfare Reform on Women's Crime. International Review of Law and Economics, 40, 1-14.

Corman, H., Dave, D.M., Reichman, N.E., \& Das, D., 2013. Effects of Welfare Reform on Illicit Drug Use of Adult Women. Economic Inquiry, 51, 653-674. 
Council of Economic Advisors, 1997. Technical Report: Explaining the Decline in Welfare Receipt. Washington, D.C.: U.S. Government Printing Office.

Dave, D. M., Reichman, N. E., \& Corman, H., 2012. Effects of Welfare Reform on Education Acquisition on Young Adult Women. Journal of Labor Research, 33(2), 251-82.

East, P.L., Weisner, T.S., \& Slonim, A., 2009. Youths' Caretaking of their Adolescent Sisters' Children: Results from Two Longitudinal Studies. J Fam Issues, 30 (12), 1671-1697.

Fang, H., \& Keane, M., 2004. Assessing the Impact of Welfare Reform on Single Mothers. Brookings Papers on Economic Activity. The Brookings Institution: Washington DC. Accessed on April 23, 2017 at: https://www.brookings.edu/bpea-articles/assessing-theimpact-of-welfare-reform-on-single-mothers/

Finkelstein, A., Taubman, S., Wright, B., Bernstein, M., Gruber, J., Newhouse, J.P., Allen, H., Baicker, K. and Oregon Health Study Group, 2012. The Oregon health insurance experiment: evidence from the first year. The Quarterly journal of economics, 127(3), pp.1057-1106.

Gennetian, L.A., Duncan, G.J., Knox, V.W., Vargas, W.G., Clark-Kauffman, E., \& London, A.S., 2002. How Welfare and Work Policies for Parents Affect Adolescents: A Synthesis of Research. Accessed on April 23, 2017 at: http://www.mdrc.org/publication/howwelfare-and-work-policies-parents-affect-adolescents

Gennetian, L.A., Duncan, G.J., Knox, V.W., Vargas, W.G., Clark-Kauffman, E., \& London, A.S., 2004. How Welfare Policies Affect Adolescents' School Outcomes: A Synthesis of Evidence from Experimental Studies. Journal of Research on Adolescence, 14 (4), 399423.

Goodman-Bacon, A., 2018. Difference-in-differences with Variation in Treatment Timing. National Bureau of Economic Research Working Paper Series (No. w25018). National Bureau of Economic Research.

Grogger, J., \& Karoly, L., 2005. Welfare Reform: Effects of a Decade of Change. Harvard University Press, Cambridge and London.

Heller, S., Shah, A., Guryan, J., Ludwig, J., Mullainathan, S., \& Pollack, H., 2017. Thinking, Fast and Slow? Some Field Experiments to Reduce Crime and Dropout in Chicago. Quarterly Journal of Economics, 132 (1), 1-54.

Hsueh, J., \& Gennetian, L.A., 2011. Welfare Policies and Adolescents: Exploring the Roles of Sibling Care, Maternal Work Schedules, and Economic Resources. Am J Community Psychol, 48 (3-4), 322-340.

Katz, Michael B. The Price of Citizenship: Redefining the American Welfare State. New York, NY: Metropolitan Books, Henry Holt \& Co., 2001.

Kaestner, R., \& Tarlov, E., 2006. Changes in the Welfare Caseload and the Health of LowEducated Mothers. Journal of Policy Analysis and Management, 25 (3), 623-643.

Kling, J.R., Ludwig, J., \& Katz, L.F., 2005. Neighborhood Effects on Crime for Female and Male Youth: Evidence from a Randomized Housing Voucher Experiment. The Quarterly Journal of Economics, 120 (1), 87-130.

Levitt, S.D., \& Lochner, L., 2001. The Determinants of Juvenile Crime. Pp. 327-374 in Gruber, J. (Ed.), Risky Behavior Among Youths: An Economic Analysis. University of Chicago Press.

Lichter, D.T., \& Jayakody, R., 2002. Welfare Reform: How Do We Measure Success? Annual Review of Sociology, 28, 117-41. 
Loeber, R., Farrington, D. P., \& Petechuk, D., 2013. Bulletin 1: From Juvenile Delinquency to Young Adult Offending (Study Group on the Transitions between Juvenile Delinquency and Adult Crime). Accessed on April 23, 2017 at: https://www.ncjrs.gov/pdffiles1/nij/grants/242931.pdf

Lopoo, L.M, \& K.M. Raissian, 2012. Natalist Policies in the United States. Journal of Policy Analysis and Management, 31 (4), 905-946.

Maclean, J. C., Tello-Trillo, S., \& Webber, D. (2019). Losing Insurance and Behavioral Health Hospitalizations: Evidence from a Large-Scale Medicaid Disenrollment (No. w25936). National Bureau of Economic Research.

Miller, A., \& Zhang, L., 2012. Intergenerational Effects of Welfare Reform on Educational Attainment. Journal of Law and Economics, 55(2), 437-76.

Moffitt, R., 2015. The Deserving Poor, the Family, and the U.S. Welfare System. Demography, 52 (3), 729-749.

Murnane, R., 2013. U.S. High School Graduation Rates: Patterns and Explanations. Journal of Economic Literature, 51(2), 370-422.

Perry, D., \& Bussey, K., 1979. The Social Learning Theory of Sex Differences: Imitation is Alive and Well. Journal of Personality and Social Psychology ,37 (10), 1699-1712.

Paxson, C., \& Waldfogel, J., 2003. Welfare Reforms, Family Resources, and Child Maltreatment. Journal of Policy Analysis and Management, 22 (1), 85-113.

Solon, G., Haider, S.J., \& Wooldridge, J.M., 2015. What are We Weighting For? Journal of Human Resources, 50(2), 301-316.

Steinberg, L. (2014). Age of Opportunity: Lessons from the New Science of Adolescence. New York: Eamon Dolan/Houghton Mifflin Harcourt.

Substance Abuse and Mental Health Services Administration, 2012. Comparing and evaluating youth substance use estimates from the National Survey on Drug Use and Health and other surveys. HHS Publication No. SMA 12-4727, Methodology Series M-9.

U.S. Department of Health and Human Services, 1999. State Implementation of Major Changes to Welfare Policies, 1992-1998. Office of the Assistant Secretary for Planning and Evaluation, Washington, DC. Accessed 5/22/15 from: http://aspe.hhs.gov/hsp/waiverpolicies99/Table_A.htm

Ziliak, J.P., 2016. Temporary Assistance for Needy Families. Pp. 303-393 in Robert A. Moffitt, (ed.), Economics of Means-Tested Transfer Programs in the United States, Volume 1. University of Chicago Press. 
Table 1

Behavioral Outcomes across Target and Comparison Groups and by Gender

Monitoring the Future (MTF) Surveys, 1991-1992

Grades $10 \& 12$ and $\leq 17 y$

\begin{tabular}{|c|c|c|c|c|c|c|}
\hline Variable & \multicolumn{3}{|c|}{ Boys } & \multicolumn{3}{|c|}{ Girls } \\
\hline Sample & Target & Comparison $\mathbf{A}$ & Comparison B & Target & Comparison $\mathbf{A}$ & Comparison $\mathrm{B}$ \\
\hline Delinquent Behavior & & & & & & \\
\hline Skipping school (past 4 weeks) & 0.279 & 0.224 & 0.273 & 0.242 & 0.210 & 0.268 \\
\hline Damaging property (past year) & 0.193 & 0.224 & 0.234 & 0.102 & 0.093 & 0.101 \\
\hline Fighting (past year) & 0.278 & 0.268 & 0.289 & 0.174 & 0.160 & 0.167 \\
\hline Stealing (past year) & 0.357 & 0.380 & 0.409 & 0.195 & 0.196 & 0.241 \\
\hline Hurting someone (past year) & 0.210 & 0.199 & 0.252 & 0.087 & 0.051 & 0.063 \\
\hline Substance Use & & & & & & \\
\hline Any substance use (past month) & 0.567 & 0.556 & 0.582 & 0.510 & 0.512 & 0.524 \\
\hline Marijuana (past month) & 0.137 & 0.102 & 0.150 & 0.102 & 0.079 & 0.109 \\
\hline Alcohol (past month) & 0.485 & 0.478 & 0.512 & 0.411 & 0.418 & 0.443 \\
\hline Cigarette smoking (past month) & 0.252 & 0.244 & 0.227 & 0.233 & 0.248 & 0.245 \\
\hline Other illicit drugs (past month) & 0.088 & 0.081 & 0.094 & 0.089 & 0.096 & 0.099 \\
\hline
\end{tabular}

Note: Weighted means for 1991 and 1992, based on the MTF sampling weights, are shown as adjusted proportions. Target group is children with unmarried mothers with a high school education or less. Comparison A is children of married mothers with a high school education or less. Comparison B is children with unmarried mothers with more than a high school education. 
Table 2

Effects of Welfare Reform on Youth Delinquent Behaviors

\section{MTF 1991-2006}

\begin{tabular}{|c|c|c|c|c|c|c|c|c|c|c|}
\hline \multirow{2}{*}{$\begin{array}{l}\text { Sample } \\
\text { Outcome }\end{array}$} & \multicolumn{5}{|c|}{$\begin{array}{c}\text { Boys } \\
\text { Grades } 10 \& 12 \text { and } \leq 17 y\end{array}$} & \multicolumn{5}{|c|}{$\begin{array}{c}\text { Girls } \\
\text { Grades } 10 \& 12 \text { and } \leq 17 y\end{array}$} \\
\hline & $\begin{array}{c}\text { Skipping } \\
\text { School }\end{array}$ & $\begin{array}{l}\text { Damaging } \\
\text { Property }\end{array}$ & Fighting & Stealing & $\begin{array}{l}\text { Hurting } \\
\text { Someone }\end{array}$ & $\begin{array}{c}\text { Skipping } \\
\text { School }\end{array}$ & $\begin{array}{l}\text { Damaging } \\
\text { Property }\end{array}$ & Fighting & Stealing & $\begin{array}{c}\text { Hurting } \\
\text { Someone }\end{array}$ \\
\hline Model & 1 & 2 & 3 & 4 & 5 & 6 & 7 & 8 & 9 & 10 \\
\hline $\begin{array}{l}\text { Welfare Reform } \\
\text { Welfare Reform*Target }\end{array}$ & $\begin{array}{c}-0.0010 \\
(0.0135) \\
0.0207 * * \\
(0.0095)\end{array}$ & $\begin{array}{c}-0.0201 * \\
(0.0106) \\
0.0414 * * * \\
(0.0108)\end{array}$ & $\begin{array}{c}-0.0216 \\
(0.0147) \\
0.0601 * * * \\
(0.0203)\end{array}$ & $\begin{array}{c}-0.0538 * * * \\
(0.0174) \\
0.0304 \\
(0.0207)\end{array}$ & $\begin{array}{c}-0.0079 \\
(0.0167) \\
0.0228 \\
(0.0175)\end{array}$ & $\begin{array}{c}-0.0165 * \\
(0.0087) \\
0.0169 * \\
(0.0093)\end{array}$ & $\begin{array}{c}0.0019 \\
(0.0085) \\
0.0075 \\
(0.0091)\end{array}$ & $\begin{array}{c}-0.0112 \\
(0.0102) \\
0.0134 \\
(0.0150)\end{array}$ & $\begin{array}{c}-0.0082 \\
(0.0122) \\
-0.0084 \\
(0.0100)\end{array}$ & $\begin{array}{c}-0.0094 \\
(0.0064) \\
-0.0068 \\
(0.0086)\end{array}$ \\
\hline $\begin{array}{l}\text { Gender Difference in } \\
\text { DDD Effect [p-value] }\end{array}$ & {$[0.7923]$} & {$[0.0130]$} & {$[0.0769]$} & {$[0.1055]$} & {$[0.1457]$} & - & - & - & - & - \\
\hline Observations & 52,359 & 20,800 & 17,477 & 20,906 & 17,411 & 66,398 & 26,481 & 22,348 & 26,570 & 22,295 \\
\hline
\end{tabular}

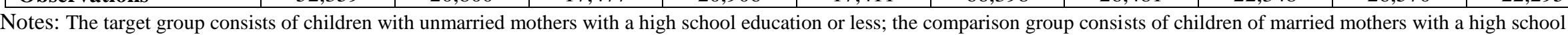

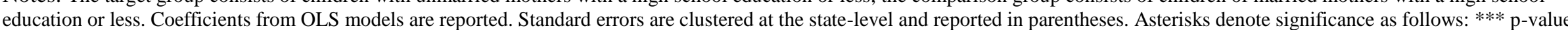

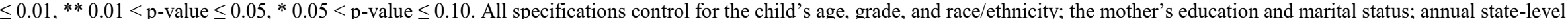

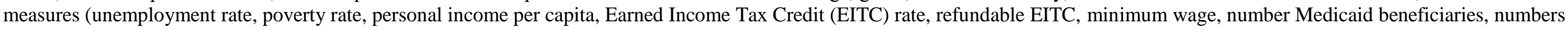
of National School Lunch and School Breakfast Program participants, and population); and indicators for state, year and month. 
Table 3

Effects of Welfare Reform on Youth Substance Use

MTF 1991-2006

\begin{tabular}{|c|c|c|c|c|c|c|c|c|c|c|}
\hline Sample & & Gra & $\begin{array}{c}\text { Boys } \\
10 \& 12 \text { ar } \\
\end{array}$ & $17 \mathrm{y}$ & & & Gra & $\begin{array}{c}\text { Girls } \\
10 \& 12 \text { an } \\
\end{array}$ & $17 y$ & \\
\hline Outcome & Marijuana & Alcohol & Smoking & $\begin{array}{l}\text { Other } \\
\text { Illicit } \\
\text { Drugs }\end{array}$ & $\begin{array}{c}\text { Any } \\
\text { Substance } \\
\text { Use }\end{array}$ & Marijuana & Alcohol & Smoking & $\begin{array}{l}\text { Other } \\
\text { Illicit } \\
\text { Drugs }\end{array}$ & $\begin{array}{c}\text { Any } \\
\text { Substance } \\
\text { Use }\end{array}$ \\
\hline Model & 1 & 2 & 3 & 4 & 5 & 6 & 7 & 8 & 9 & 10 \\
\hline $\begin{array}{l}\text { Welfare Reform } \\
\text { Welfare Reform*Target }\end{array}$ & $\begin{array}{c}0.0005 \\
(0.0145) \\
0.0321 * * * \\
(0.0064)\end{array}$ & $\begin{array}{c}0.0093 \\
(0.0115) \\
0.0168 \\
(0.0116)\end{array}$ & $\begin{array}{c}-0.0070 \\
(0.0107) \\
0.0229 * * \\
(0.0097)\end{array}$ & $\begin{array}{c}-0.0120 * * \\
(0.0058) \\
0.0190 * * \\
(0.0082)\end{array}$ & $\begin{array}{c}0.0056 \\
(0.0103) \\
0.0329 * * * \\
(0.0079)\end{array}$ & $\begin{array}{c}0.0064 \\
(0.0095) \\
0.0250 * * * \\
(0.0063)\end{array}$ & $\begin{array}{c}0.0107 \\
(0.0180) \\
0.0132 \\
(0.0091)\end{array}$ & $\begin{array}{c}-0.0085 \\
(0.0155) \\
0.0288 * * * \\
(0.0093)\end{array}$ & $\begin{array}{c}0.0057 \\
(0.0050) \\
0.0020 \\
(0.0063)\end{array}$ & $\begin{array}{c}0.0097 \\
(0.0194) \\
0.0226 * * \\
(0.0102)\end{array}$ \\
\hline $\begin{array}{l}\text { Gender Difference in } \\
\text { DDD Effect [p-value] }\end{array}$ & {$[0.4820]$} & {$[0.7938]$} & {$[0.6878]$} & {$[0.0381]$} & {$[0.4258]$} & - & - & - & - & - \\
\hline Observations & 54,225 & 52,473 & 54,458 & 55,265 & 52,835 & 68,596 & 66,285 & 68,632 & 69,575 & 66,719 \\
\hline
\end{tabular}

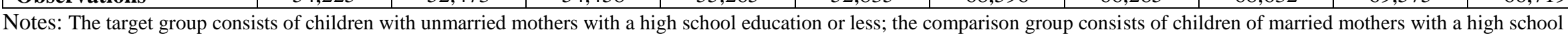

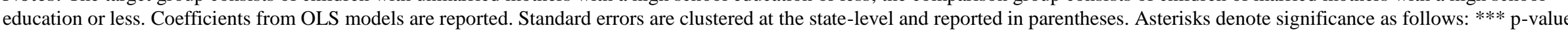

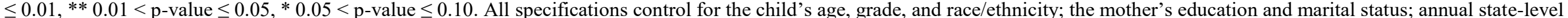

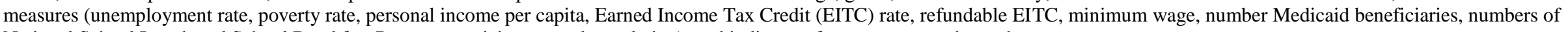
National School Lunch and School Breakfast Program participants, and population); and indicators for state, year and month. 
Table 4

Standardized Treatment Effects and Cross-equation Estimates of the Average Effect of Welfare Reform on Youth Behavior MTF 1991-2006

\begin{tabular}{|c|c|c|c|c|c|c|}
\hline \multirow{2}{*}{$\begin{array}{l}\text { Sample } \\
\text { Model } \\
\end{array}$} & \multicolumn{3}{|c|}{$\begin{array}{c}\text { Boys } \\
\text { Grades } 10 \& 12 \text { and } \leq 17 y \\
\end{array}$} & \multicolumn{3}{|c|}{$\begin{array}{c}\text { Girls } \\
\text { Grades } 10 \& 12 \text { and } \leq 17 y\end{array}$} \\
\hline & 1 & 2 & 3 & 4 & 5 & 6 \\
\hline \multirow[t]{2}{*}{ Outcomes } & $\begin{array}{c}\text { Delinquent } \\
\text { Behaviors }\end{array}$ & Substance Use & All Behaviors & $\begin{array}{c}\text { Delinquent } \\
\text { Behaviors }\end{array}$ & Substance Use & All Behaviors \\
\hline & \multicolumn{6}{|c|}{ Average Standardized Treatment Effect } \\
\hline Welfare Reform & $\begin{array}{c}-0.0471 * * \\
(0.0208) \\
{[0.023]}\end{array}$ & $\begin{array}{c}-0.0090 \\
(0.0200) \\
{[0.653]}\end{array}$ & $\begin{array}{c}-0.0302 * \\
(0.0174) \\
{[0.083]}\end{array}$ & $\begin{array}{c}-0.0246 * \\
(0.0137) \\
{[0.071]}\end{array}$ & $\begin{array}{c}0.0098 \\
(0.0250) \\
{[0.694]}\end{array}$ & $\begin{array}{c}-0.0093 \\
(0.0151) \\
{[0.538]}\end{array}$ \\
\hline $\begin{array}{l}\text { Welfare Reform*Target } \\
\text { (Average DDD effect) }\end{array}$ & $\begin{array}{c}0.0828 * * * \\
(0.0257) \\
{[0.001]}\end{array}$ & $\begin{array}{c}0.0581 * * * \\
(0.0144) \\
{[0.000]}\end{array}$ & $\begin{array}{c}0.0718 * * * \\
(0.0161) \\
{[0.000]}\end{array}$ & $\begin{array}{c}0.0113 \\
(0.0183) \\
{[0.538]}\end{array}$ & $\begin{array}{c}0.0424 * * * \\
(0.0110) \\
{[0.000]}\end{array}$ & $\begin{array}{c}0.0251 * * \\
(0.0124) \\
{[0.043]}\end{array}$ \\
\hline $\begin{array}{l}\text { Gender Difference in } \\
\text { DDD Effect [p-value] }\end{array}$ & {$[0.004]$} & {$[0.333]$} & {$[0.009]$} & - & - & - \\
\hline Welfare Reform & $\begin{array}{c}-0.0467 * * \\
(0.0205) \\
{[0.023]}\end{array}$ & $\begin{array}{c}-0.0089 \\
(0.0197) \\
{[0.652]}\end{array}$ & $\begin{array}{c}-0.0299 * \\
(0.0172) \\
{[0.082]}\end{array}$ & $\begin{array}{c}-0.0240 * \\
(0.0134) \\
{[0.073]}\end{array}$ & $\begin{array}{c}0.0097 \\
(0.0248) \\
{[0.696]}\end{array}$ & $\begin{array}{c}-0.0090 \\
(0.0149) \\
{[0.546]}\end{array}$ \\
\hline $\begin{array}{l}\text { Welfare Reform*Target } \\
\text { (Average DDD effect) }\end{array}$ & $\begin{array}{c}0.0818 * * * \\
(0.0254) \\
{[0.001]}\end{array}$ & $\begin{array}{c}0.0574 * * * \\
(0.0143) \\
{[0.000]}\end{array}$ & $\begin{array}{c}0.0709 * * * \\
(0.0159) \\
{[0.000]}\end{array}$ & $\begin{array}{c}0.0112 \\
(0.0179) \\
{[0.531]}\end{array}$ & $\begin{array}{c}0.0419 * * * \\
(0.0110) \\
{[0.000]}\end{array}$ & $\begin{array}{c}0.0248 * * \\
(0.0122) \\
{[0.041]}\end{array}$ \\
\hline $\begin{array}{l}\text { Gender Difference in } \\
\text { DDD Effect [p-value] }\end{array}$ & {$[0.004]$} & {$[0.335]$} & [0.009] & - & - & - \\
\hline
\end{tabular}

Notes: The target group consists of children with unmarried mothers with a high school education or less; the comparison group consists of children of married mothers with a high school education or less. Delinquent behaviors are skipping school, damaging property, fighting, stealing, and hurting someone. Substance use behaviors are using marijuana, consuming alcohol, smoking, and using illicit drugs. All behaviors include all of the delinquent and substance use behaviors. The top panel represents the mean standardized treatment effect across all outcomes, which is the coefficient/standard deviation of outcome for the control group. In the bottom panel, models are jointly estimated using a seemingly unrelated regression (SUR) framework. In this case, all outcomes are redefined as standard normal deviates (see text). Two sets of results are presented for each model: (1) P-values from joint significance tests across all noted outcomes are reported in the first results row in square brackets; (2) Average effects across all noted outcomes from the DDD specification, with state-clustered standard errors reported in parentheses and the p-value reported in square brackets. Asterisks denote significance as follows: $* * * \mathrm{p}$-value $\leq 0.01, * * 0.01<\mathrm{p}$-value $\leq 0.05, * 0.05<\mathrm{p}$-value $\leq 0.10$. All specifications control for the child's age, grade, and race/ethnicity; the mother's education and marital status; annual state-level measures (unemployment rate, poverty rate, personal income per capita, Earned Income Tax Credit (EITC) rate, refundable EITC, minimum wage, number Medicaid beneficiaries, numbers of National School Lunch and School Breakfast Program participants, and population); and indicators for state, year and month. 


\section{Table 5}

\section{Cross-equation Estimates of the Average Effect of Welfare Reform on Youth Behaviors Event Study: Lead and Lag Effects of Welfare Reform MTF 1991-2006 \\ Boys, Grades $10 \& 12$ and $\leq 17$ y}

\begin{tabular}{|c|c|c|c|}
\hline Model & 1 & 2 & 3 \\
\hline Outcomes & Delinquent Behaviors & Substance Use & All Behaviors \\
\hline \multicolumn{4}{|l|}{ Average DDD Effect } \\
\hline Pre WR 5+ Years*Target & $\begin{array}{c}0.0833 \\
(0.0562)\end{array}$ & $\begin{array}{c}0.0897 * * \\
(0.0398)\end{array}$ & $\begin{array}{c}0.0862 * * \\
(0.0389)\end{array}$ \\
\hline \multirow[t]{2}{*}{ Pre WR 4 Years*Target } & 0.00004 & 0.0544 & 0.0242 \\
\hline & $(0.0638)$ & $(0.0370)$ & $(0.0390)$ \\
\hline \multirow[t]{2}{*}{ Pre WR 3 Years*Target } & -0.0110 & 0.0457 & 0.0142 \\
\hline & $(0.0561)$ & $(0.0414)$ & $(0.0385)$ \\
\hline Pre WR 2 Years*Target & $\begin{array}{c}0.0603 \\
(0.0512)\end{array}$ & $\begin{array}{c}0.0191 \\
(0.0356)\end{array}$ & $\begin{array}{c}0.0420 \\
(0.0354)\end{array}$ \\
\hline Pre WR 1 Year*Target & - & - & - \\
\hline Joint Significance on Leads [p-value] & [0.1041] & {$[0.1941]$} & [0.1294] \\
\hline \multirow[t]{2}{*}{ Post WR 1 Year*Target } & $0.1243 *$ & 0.0331 & $0.0838 *$ \\
\hline & $(0.0669)$ & $(0.0413)$ & $(0.0477)$ \\
\hline \multirow[t]{2}{*}{ Post WR 2 Years*Target } & 0.1213 & $0.0972 * *$ & $0.1106^{*}$ \\
\hline & $(0.0863)$ & $(0.0464)$ & $(0.0600)$ \\
\hline \multirow[t]{2}{*}{ Post WR 3 Years*Target } & $0.1512 *$ & $0.0886 * *$ & $0.1234 * *$ \\
\hline & $(0.0814)$ & $(0.0386)$ & $(0.0565)$ \\
\hline \multirow[t]{2}{*}{ Post WR 4+ Years*Target } & $0.1276 * * *$ & $0.0991 * * *$ & $0.1150 * * *$ \\
\hline & $(0.0439)$ & $(0.0264)$ & $(0.0276)$ \\
\hline
\end{tabular}

Notes: The target group consists of children with unmarried mothers with a high school education or less; the comparison group consists of children of married mothers with a high school education or less. Delinquent behaviors are skipping school, damaging property, fighting, stealing, and hurting someone. Substance use behaviors are using marijuana, consuming alcohol, smoking, and using illicit drugs. All behaviors include all of the delinquent and substance use behaviors. Models are jointly estimated using a seemingly unrelated regression (SUR) framework. All outcomes are redefined as standard normal deviates (see text). Each column in each panel presents estimates from a separate model. Estimates of the average effect of welfare reform across all noted outcomes are reported, with stateclustered standard errors reported in parentheses. All specifications control for the child's age, grade, and race/ethnicity; the mother's education and marital status; annual state-level measures (unemployment rate, poverty rate, personal income per capita, Earned Income Tax Credit (EITC) rate, refundable EITC, minimum wage, number Medicaid beneficiaries, numbers of National School Lunch and School Breakfast Program participants, and population); and indicators for state, year and month. Asterisks denote significance as follows: $* * * \mathrm{p}-$ value $\leq 0.01, * * 0.01<$ p-value $\leq 0.05, * 0.05<$ p-value $\leq 0.10$. 
Table 6

\section{Cross-equation Estimates of the Average Effect of Welfare Reform on Youth Behaviors Event Study: Lead and Lag Effects of Welfare Reform MTF 1991-2006 \\ Girls, Grades 10 \& 12 and $\leq 17$ y}

\begin{tabular}{|c|c|c|c|}
\hline Model & 1 & 2 & 3 \\
\hline Outcomes & Delinquent Behaviors & Substance Use & All Behaviors \\
\hline Average DDD Effect & & & \\
\hline Pre WR 5+ Years*Target & $\begin{array}{l}-0.0551 \\
(0.0392)\end{array}$ & $\begin{array}{l}-0.0123 \\
(0.0335)\end{array}$ & $\begin{array}{l}-0.0361 \\
(0.0290)\end{array}$ \\
\hline Pre WR 4 Years*Target & $\begin{array}{l}-0.0239 \\
(0.0339)\end{array}$ & $\begin{array}{l}-0.0101 \\
(0.0369)\end{array}$ & $\begin{array}{l}-0.0178 \\
(0.0263)\end{array}$ \\
\hline Pre WR 3 Years*Target & $\begin{array}{l}-0.0042 \\
(0.0552)\end{array}$ & $\begin{array}{l}-0.0180 \\
(0.0437)\end{array}$ & $\begin{array}{l}-0.0103 \\
(0.0424)\end{array}$ \\
\hline Pre WR 2 Years*Target & $\begin{array}{c}0.0058 \\
(0.0427)\end{array}$ & $\begin{array}{c}0.0410 \\
(0.0332)\end{array}$ & $\begin{array}{c}0.0214 \\
(0.0284)\end{array}$ \\
\hline Pre WR 1 Year*Target & - & - & - \\
\hline Joint Significance on Leads [p-value] & {$[0.5103]$} & {$[0.4080]$} & {$[0.4011]$} \\
\hline Post WR 1 Year*Target & $\begin{array}{l}-0.0526^{*} \\
(0.0309)\end{array}$ & $\begin{array}{l}-0.0050 \\
(0.0289)\end{array}$ & $\begin{array}{l}-0.0314 \\
(0.0218)\end{array}$ \\
\hline Post WR 2 Years*Target & $\begin{array}{c}0.0068 \\
(0.0477)\end{array}$ & $\begin{array}{c}0.0369 \\
(0.0387)\end{array}$ & $\begin{array}{c}0.0202 \\
(0.0355)\end{array}$ \\
\hline Post WR 3+ Years*Target & $\begin{array}{l}-0.0227 \\
(0.0518)\end{array}$ & $\begin{array}{c}0.0448 \\
(0.0371)\end{array}$ & $\begin{array}{c}0.0073 \\
(0.0323)\end{array}$ \\
\hline Post WR 4+ Years*Target & $\begin{array}{l}-0.0132 \\
(0.0353)\end{array}$ & $\begin{array}{l}0.0431^{*} \\
(0.0263)\end{array}$ & $\begin{array}{c}0.0118 \\
(0.0227)\end{array}$ \\
\hline
\end{tabular}

Notes: The target group consists of children with unmarried mothers with a high school education or less; the comparison group consists of children of married mothers with a high school education or less. Delinquent behaviors are skipping school, damaging property, fighting, stealing, and hurting someone. Substance use behaviors are using marijuana, consuming alcohol, smoking, and using illicit drugs. All behaviors include all of the delinquent and substance use behaviors. Models are jointly estimated using a seemingly unrelated regression (SUR) framework. All outcomes are redefined as standard normal deviates (see text). Each column in each panel presents estimates from a separate model. Estimates of the average effect of welfare reform across all noted outcomes are reported, with state-clustered standard errors reported in parentheses. All specifications control for the child's age, grade, and race/ethnicity; the mother's education and marital status; annual state-level measures (unemployment rate, poverty rate, personal income per capita, Earned Income Tax Credit (EITC) rate, refundable EITC, minimum wage, number Medicaid beneficiaries, numbers of National School Lunch and School Breakfast Program participants, and population); and indicators for state, year and month. Asterisks denote significance as follows: *** p-value $\leq$ $0.01, * * 0.01<\mathrm{p}$-value $\leq 0.05, * 0.05<\mathrm{p}$-value $\leq 0.10$. 
Table 7

Standardized Treatment Effects and Cross-equation Estimates of the Average Effect of Welfare Reform on Youth Behavior Placebo Group: Children of Married Mothers with a College Degree or More MTF 1991-2006

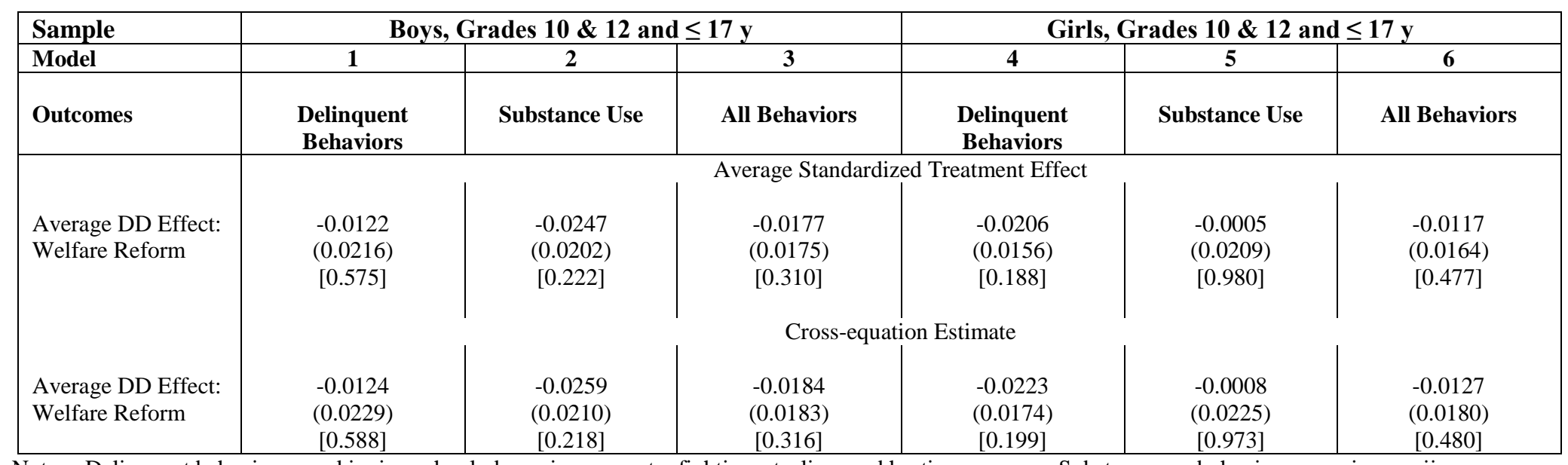

Notes: Delinquent behaviors are skipping school, damaging property, fighting, stealing, and hurting someone. Substance use behaviors are using marijuana, consuming alcohol, smoking, and using illicit drugs. All behaviors include all of the delinquent and substance use behaviors. The top panel represents the mean standardized treatment effect across all outcomes, which is the coefficient/standard deviation of outcome for the control group. For the bottom panel, models are jointly estimated using a seemingly unrelated regression framework. All outcomes are redefined as standard normal deviates (see text). Estimate of the average effect of welfare reform (average DD effect) across all noted outcomes is reported for the placebo group, with state-clustered standard errors reported in parentheses and the p-value reported in square brackets. All specifications control for the child's age, grade, and race/ethnicity; the mother's education and marital status; annual state-level measures (unemployment rate, poverty rate, personal income per capita, Earned Income Tax Credit (EITC) rate, refundable EITC, minimum wage, number Medicaid beneficiaries, numbers of National School Lunch and School Breakfast Program participants, and population); and indicators for state, year and month. Asterisks denote significance as follows: $* * *$ p-value $\leq 0.01, * * 0.01<\mathrm{p}$-value $\leq 0.05, * 0.05<\mathrm{p}$-value $\leq 0.10$. 
Appendix Table 1: Implementation Dates of Welfare Reform by State, U.S.

\begin{tabular}{|c|c|c|c|c|c|c|c|}
\hline & $\begin{array}{c}10 / 92 \text { to } 2 / 97 \\
\text { AFDC Waiver }\end{array}$ & $\begin{array}{c}9 / 96 \text { to } 1 / 98 \\
\text { TANF } \\
\end{array}$ & $\begin{array}{c}10 / 92 \text { to } 1 / 98 \\
\text { Any Welfare Reform }\end{array}$ & & $\begin{array}{c}10 / 92 \text { to } 2 / 97 \\
\text { AFDC Waiver }\end{array}$ & $\begin{array}{c}9 / 96 \text { to } 1 / 98 \\
\text { TANF } \\
\end{array}$ & $\begin{array}{c}10 / 92 \text { to } 1 / 98 \\
\text { Any Welfare Reform }\end{array}$ \\
\hline Alabama & & Nov-96 & Nov-96 & Montana & Feb-96 & Feb-97 & Feb-96 \\
\hline Alaska & & Jul-97 & Jul-97 & Nebraska & Oct-95 & Dec-96 & Oct-95 \\
\hline Arizona & Nov-95 & Oct-96 & Nov-95 & Nevada & & Dec-96 & Dec-96 \\
\hline Arkansas & Jul-94 & Jul-97 & Jul-94 & New Hampshire & & Oct-96 & Oct-96 \\
\hline California & Dec-92 & Jan-98 & Dec-92 & New Jersey & Oct-92 & Jul-97 & Oct-92 \\
\hline Colorado & & Jul-97 & Jul-97 & New Mexico & & Jul-97 & Jul-97 \\
\hline Connecticut & Jan-96 & Oct-96 & Jan-96 & New York & & Nov-97 & Nov-97 \\
\hline DC & & Mar-97 & Mar-97 & North Carolina & Jul-96 & Jan-97 & Jul-96 \\
\hline Delaware & Oct-95 & Mar-97 & Oct-95 & North Dakota & & Jul-97 & Jul-97 \\
\hline Florida & & & Oct-96 & Ohio & Jul-96 & Oct-96 & Jul-96 \\
\hline Georgia & Jan-94 & Jan-97 & Jan-94 & Oklahoma & & Oct-96 & Oct-96 \\
\hline Hawaii & Feb-97 & Jul-97 & Feb-97 & Oregon & Feb-93 & Oct-96 & Feb-93 \\
\hline Idaho & & Jul-97 & Jul-97 & Pennsylvania & & Mar-97 & Mar-97 \\
\hline Illinois & Nov-93 & Jul-97 & Nov-93 & Rhode Island & & May-97 & May-97 \\
\hline Indiana & May-95 & Oct-96 & May-95 & South Carolina & & Oct-96 & Oct-96 \\
\hline Iowa & Oct-93 & Jan-97 & Oct-93 & South Dakota & Jun-94 & Dec-96 & Jun-94 \\
\hline Kansas & & Oct-96 & Oct-96 & Tennessee & Sep-96 & Oct-96 & Sep-96 \\
\hline Kentucky & & Oct-96 & Oct-96 & Texas & Jun-96 & Nov-96 & Jun-96 \\
\hline Louisiana & & Jan-97 & Jan-97 & Utah & Jan-93 & Oct-96 & Jan-93 \\
\hline Maine & & Nov-96 & Nov-96 & Vermont & Jul-94 & Sep-96 & Jul-94 \\
\hline Maryland & Mar-96 & Dec-96 & Mar-96 & Virginia & Jul-95 & Feb-97 & Jul-95 \\
\hline Massachusetts & Nov-95 & Sep-96 & Nov-95 & Washington & Jan-96 & Jan-97 & Jan-96 \\
\hline Michigan & Oct-92 & Sep-96 & Oct-92 & West Virginia & & Jan-97 & Jan-97 \\
\hline Minnesota & & Jul-97 & Jul-97 & Wisconsin & Jan-96 & Sep-97 & Jan-96 \\
\hline Mississippi & Oct-95 & Jul-97 & Oct-95 & Wyoming & & Jan-97 & Jan-97 \\
\hline Missouri & Jun-95 & Dec-96 & Jun-95 & & & & \\
\hline
\end{tabular}




\section{Appendix Table 2 \\ Behavioral Outcomes and Sample Characteristics \\ Across Target and Comparison Groups by Gender \\ Monitoring the Future (MTF) Surveys 1991-2006 \\ Children in Grades 10 \& 12 and $\leq 17$ y}

\begin{tabular}{|l|c|c|c|c|}
\hline Variable & \multicolumn{2}{|c|}{ Boys } & \multicolumn{2}{c|}{ Girls } \\
Sample & Target & Comparison & Target & Comparison \\
\hline Behavioral Outcomes & & & & \\
Delinquent behaviors & 0.286 & 0.222 & 0.260 & 0.216 \\
Skipping school (past 4 weeks) & 0.229 & 0.210 & 0.106 & 0.096 \\
Damaging property (past year) & 0.289 & 0.238 & 0.178 & 0.143 \\
Fighting (past year) & 0.375 & 0.340 & 0.231 & 0.215 \\
Stealing (past year) & 0.245 & 0.201 & 0.095 & 0.062 \\
Hurting someone (past year) & & & & \\
Substance use & & & & \\
Marijuana use (past month) & 0.251 & 0.179 & 0.190 & 0.143 \\
Alcohol consumption (past month) & 0.459 & 0.445 & 0.412 & 0.401 \\
Cigarette smoking (past month) & 0.273 & 0.250 & 0.271 & 0.263 \\
Other illicit drug use (past month) & 0.119 & 0.103 & 0.114 & 0.104 \\
Any substance use (past month) & 0.572 & 0.538 & 0.535 & 0.509 \\
Sample characteristics & & & & \\
Age (years) & & & & 16.05 \\
Grade 10 & 16.07 & 16.03 & 0.694 & 0.686 \\
Grade 12 & 0.746 & 0.727 & 0.306 & 0.314 \\
White & 0.255 & 0.273 & 0.494 & 0.701 \\
Black & 0.506 & 0.709 & 0.280 & 0.075 \\
Other race/ethnicity (includes Hispanics) & 0.253 & 0.064 & 0.226 & 0.224 \\
Mother: Married & 0.0 & 0.227 & 0.289 & 1.0 \\
Mother: Less than high school graduate & 0.239 & 0.178 & 0.641 & 0.718 \\
Mother: High school graduate & 0.700 & 0.766 & & \\
Observations & 11,136 & 44,129 & 16,415 & 53,160 \\
\hline
\end{tabular}

Notes: Weighted means, based on the MTF sampling weights, are reported as column \%s. The target group consists of children with unmarried mothers with a high school education or less; the comparison group consists of children of married mothers with a high school education or less. Reported number of observations is the maximum sample size; sample sizes are smaller for some variables owing to missing data. 


\section{Appendix Table 3 \\ Effects of Welfare Reform on Youth Delinquent Behaviors Difference-in-Differences for Target and Comparison Groups MTF 1991-2006}

\begin{tabular}{|c|c|c|c|c|c|c|c|c|c|c|}
\hline \multirow{2}{*}{$\begin{array}{l}\text { Sample } \\
\text { Outcome }\end{array}$} & \multicolumn{5}{|c|}{$\begin{array}{cl}\text { Boys } \\
\text { Grades } 10 \& 12 \text { and } \leq 17 y\end{array}$} & \multicolumn{5}{|c|}{$\begin{array}{c}\text { Girls } \\
\text { Grades } 10 \& 12 \text { and } \leq 17 y \\
\end{array}$} \\
\hline & $\begin{array}{c}\text { Skipping } \\
\text { School }\end{array}$ & $\begin{array}{l}\text { Damaging } \\
\text { Property }\end{array}$ & Fighting & Stealing & $\begin{array}{l}\text { Hurting } \\
\text { Someone }\end{array}$ & $\begin{array}{c}\text { Skipping } \\
\text { School }\end{array}$ & $\begin{array}{c}\text { Damaging } \\
\text { Property }\end{array}$ & Fighting & Stealing & $\begin{array}{l}\text { Hurting } \\
\text { Someone }\end{array}$ \\
\hline Model & 1 & 2 & 3 & 4 & 5 & 6 & 7 & 8 & 9 & 10 \\
\hline Welfare Reform & $\begin{array}{c}0.0406 \\
(0.0277)\end{array}$ & $\begin{array}{c}0.0061 \\
(0.0348)\end{array}$ & $\begin{array}{c}\text { Target Gro } \\
0.0479 \\
(0.0513)\end{array}$ & $\begin{array}{c}\text { Children o } \\
\begin{array}{c}-0.0357 \\
(0.0449)\end{array}\end{array}$ & $\begin{array}{c}\text { nmarried } \mathrm{N} \\
0.0388 \\
(0.0425)\end{array}$ & $\begin{array}{l}\text { ers with } \mathrm{Hi} \\
\quad-0.0105 \\
(0.0172)\end{array}$ & $\begin{array}{c}\text { School Educ } \\
0.0068 \\
(0.0225)\end{array}$ & $\begin{array}{l}\text { ion or Less } \\
-0.0084 \\
(0.0268)\end{array}$ & $\begin{array}{c}0.0189 \\
(0.0290)\end{array}$ & $\begin{array}{l}-0.0080 \\
(0.0185)\end{array}$ \\
\hline Welfare Reform & $\begin{array}{l}-0.0068 \\
(0.0134)\end{array}$ & $\begin{array}{c}-0.0235^{* *} \\
(0.0115)\end{array}$ & $\begin{array}{l}\text { omparison } \\
-0.0269 * * \\
(0.0115)\end{array}$ & $\begin{array}{l}\text { oup: Childr } \\
-0.0423^{* *} \\
(0.0174)\end{array}$ & $\begin{array}{l}\text { of Married } \\
-0.0172 \\
(0.0180)\end{array}$ & $\begin{array}{l}\text { thers with } \mathrm{H} \\
\begin{array}{c}-0.0158 \\
(0.0110)\end{array}\end{array}$ & $\begin{array}{c}\text { School Ed } \\
0.0047 \\
(0.0095)\end{array}$ & $\begin{array}{l}\text { ation or Le } \\
-0.0070 \\
(0.0116)\end{array}$ & $\begin{array}{l}-0.0166 \\
(0.0111)\end{array}$ & $\begin{array}{l}-0.0040 \\
(0.0073)\end{array}$ \\
\hline & & & Difference & Difference & Difference & timate (D & $\operatorname{arget}-\mathrm{DD}$ & mparison) & & \\
\hline Welfare Reform & $\begin{array}{l}0.0475^{*} \\
(0.0281)\end{array}$ & $\begin{array}{c}0.0296 \\
(0.0371)\end{array}$ & $\begin{array}{c}0.0747 \\
(0.0479)\end{array}$ & $\begin{array}{c}0.0066 \\
(0.0484)\end{array}$ & $\begin{array}{c}0.0560 \\
(0.0416)\end{array}$ & $\begin{array}{c}0.0053 \\
(0.0196)\end{array}$ & $\begin{array}{c}0.0021 \\
(0.0218)\end{array}$ & $\begin{array}{l}-0.0014 \\
(0.0273)\end{array}$ & $\begin{array}{c}0.0355 \\
(0.0274)\end{array}$ & $\begin{array}{l}-0.0040 \\
(0.0193)\end{array}$ \\
\hline Observations & 52,359 & 20,800 & 17,477 & 20,906 & 17,411 & 66,398 & 26,481 & 22,348 & 26,570 & 22,295 \\
\hline
\end{tabular}

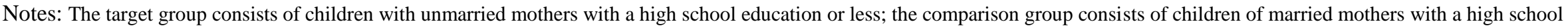

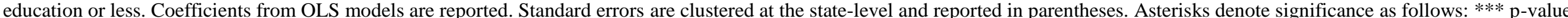

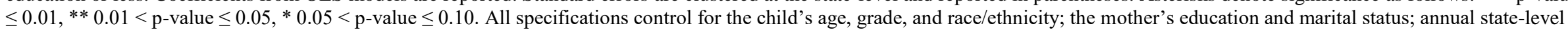

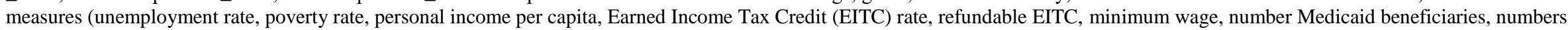
of National School Lunch and School Breakfast Program participants, and population); and indicators for state, year and month. 


\section{Appendix Table 4 \\ Effects of Welfare Reform on Youth Substance Use \\ Difference-in-Differences for Target and Comparison Groups \\ MTF 1991-2006}

\begin{tabular}{|c|c|c|c|c|c|c|c|c|c|c|}
\hline \multirow{2}{*}{$\begin{array}{l}\text { Sample } \\
\text { Outcome }\end{array}$} & \multicolumn{5}{|c|}{$\begin{array}{c}\text { Boys } \\
\text { Grades } 10 \& 12 \text { and } \leq 17 y\end{array}$} & \multicolumn{5}{|c|}{$\begin{array}{c}\text { Girls } \\
\text { Grades } 10 \& 12 \text { and } \leq 17 y\end{array}$} \\
\hline & Marijuana & Alcohol & Smoking & $\begin{array}{c}\text { Other } \\
\text { Illicit } \\
\text { Drugs }\end{array}$ & $\begin{array}{c}\text { Any } \\
\text { Substance } \\
\text { Use }\end{array}$ & Marijuana & Alcohol & Smoking & $\begin{array}{l}\text { Other } \\
\text { Illicit } \\
\text { Drugs }\end{array}$ & $\begin{array}{c}\text { Any } \\
\text { Substance } \\
\text { Use }\end{array}$ \\
\hline Model & 1 & 2 & 3 & 4 & 5 & 6 & 7 & 8 & 9 & 10 \\
\hline Welfare Reform & $\begin{array}{c}0.0545^{* * * *} \\
(0.0155)\end{array}$ & $\begin{array}{l}0.0415^{*} \\
(0.0215)\end{array}$ & $\begin{array}{c}\text { Target Grou } \\
\\
0.0257 \\
(0.0194)\end{array}$ & $\begin{array}{c}\text { Children of } \\
0.0362 * \\
(0.0141)\end{array}$ & $\begin{array}{c}\text { nmarried Mc } \\
0.0583 * * * \\
(0.0158)\end{array}$ & $\begin{array}{l}\text { hers with High } \\
\\
0.0266 \\
(0.0177)\end{array}$ & $\begin{array}{c}\text { school Edu } \\
0.0259 \\
(0.0163)\end{array}$ & $\begin{array}{c}\text { ion or Less } \\
0.0027 \\
(0.0169)\end{array}$ & $\begin{array}{l}-0.0016 \\
(0.0108)\end{array}$ & $\begin{array}{c}0.0223 \\
(0.0199)\end{array}$ \\
\hline Welfare Reform & $\begin{array}{l}-0.0084 \\
(0.0159)\end{array}$ & $\begin{array}{l}-0.0069 \\
(0.0120)\end{array}$ & $\begin{array}{c}\text { omparison } \\
\begin{array}{c}-0.0136 \\
(0.0120)\end{array}\end{array}$ & $\begin{array}{l}\text { sup: Childrer } \\
-0.0189 * * * \\
(0.0066)\end{array}$ & $\begin{array}{l}\text { of Married N } \\
\begin{array}{c}-0.0119 \\
(0.0107)\end{array}\end{array}$ & $\begin{array}{c}\text { thers with } \mathrm{Hi} \\
\quad 0.0134 \\
(0.0101)\end{array}$ & $\begin{array}{c}\text { School Ec } \\
0.0050 \\
(0.0206)\end{array}$ & $\begin{array}{l}\text { tion or Le } \\
-0.0024 \\
(0.0163)\end{array}$ & $\begin{array}{c}0.0070 \\
(0.0057)\end{array}$ & $\begin{array}{c}0.0137 \\
(0.0207)\end{array}$ \\
\hline & \multicolumn{10}{|c|}{ Difference-in-Difference-in-Differences Estimate (DD Target - DD Comparison) } \\
\hline Welfare Reform & $\begin{array}{c}0.0629 * * * \\
(0.0178)\end{array}$ & $\begin{array}{l}0.0484 * * \\
(0.0224)\end{array}$ & $\begin{array}{l}0.0394^{*} \\
(0.0219)\end{array}$ & $\begin{array}{c}0.0551 * * * \\
(0.0152)\end{array}$ & $\begin{array}{c}0.0702 * * * \\
(0.0189)\end{array}$ & $\begin{array}{c}0.0132 \\
(0.0182)\end{array}$ & $\begin{array}{c}0.0209 \\
(0.0206)\end{array}$ & $\begin{array}{c}0.0052 \\
(0.0163)\end{array}$ & $\begin{array}{l}-0.0087 \\
(0.0117)\end{array}$ & $\begin{array}{c}0.0086 \\
(0.0190)\end{array}$ \\
\hline Observations & 54,225 & 52,473 & 54,458 & 55,265 & 52,835 & 68,596 & 66,285 & 68,632 & 69,575 & 66,719 \\
\hline
\end{tabular}

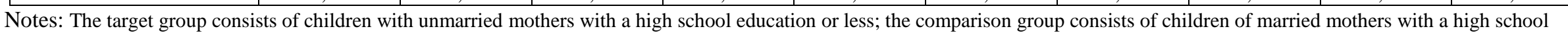

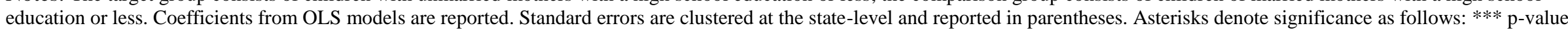

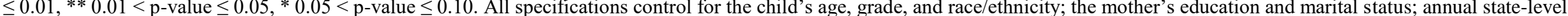

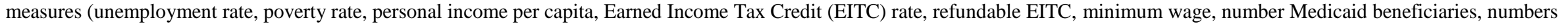
of National School Lunch and School Breakfast Program participants, and population); and indicators for state, year and month. 
Appendix Table 5

Effects of Welfare Reform on Youth Behaviors

Separate Effects of AFDC Waiver \& TANF

MTF 1991-2006

\begin{tabular}{|c|c|c|c|c|c|c|c|c|c|c|}
\hline Outcome & $\begin{array}{c}\text { Skipping } \\
\text { School }\end{array}$ & $\begin{array}{l}\text { Damage } \\
\text { Property }\end{array}$ & Fight & Steal & $\begin{array}{c}\text { Hurt } \\
\text { Someone }\end{array}$ & $\begin{array}{c}\text { Any } \\
\text { Substance } \\
\text { Use } \\
\end{array}$ & Marijuana & Alcohol & Smoking & $\begin{array}{c}\text { Other Illicit } \\
\text { Drugs }\end{array}$ \\
\hline Sample & \multicolumn{10}{|c|}{$\begin{array}{c}\text { Boys } \\
\text { des } 10 \& 12 \text { and } \leq 17 y\end{array}$} \\
\hline AFDC Waiver & $\begin{array}{l}-0.0055 \\
(0.0137)\end{array}$ & $\begin{array}{l}-0.0202 * \\
(0.0118)\end{array}$ & $\begin{array}{c}-0.0288^{* *} \\
(0.0131)\end{array}$ & $\begin{array}{c}-0.0561 * * * \\
(0.0182)\end{array}$ & $\begin{array}{l}-0.0160 \\
(0.0156)\end{array}$ & $\begin{array}{c}0.0005 \\
(0.0114)\end{array}$ & $\begin{array}{l}-0.0032 \\
(0.0160)\end{array}$ & $\begin{array}{c}0.0096 \\
(0.0126)\end{array}$ & $\begin{array}{l}-0.0107 \\
(0.0121)\end{array}$ & $\begin{array}{c}-0.0137 * * \\
(0.0064)\end{array}$ \\
\hline TANF & $\begin{array}{c}0.0181 \\
(0.0244)\end{array}$ & $\begin{array}{l}-0.0092 \\
(0.0228)\end{array}$ & $\begin{array}{l}0.0116 \\
(0.0321)\end{array}$ & $\begin{array}{c}-0.0578^{* *} \\
(0.0285)\end{array}$ & $\begin{array}{c}0.0028 \\
(0.0317)\end{array}$ & $\begin{array}{c}0.0370^{* *} \\
(0.0171)\end{array}$ & $\begin{array}{c}0.0295 \\
(0.0201)\end{array}$ & $\begin{array}{c}0.0137 \\
(0.0165)\end{array}$ & $\begin{array}{c}0.0159 \\
(0.0176)\end{array}$ & $\begin{array}{l}-0.0067 \\
(0.0125)\end{array}$ \\
\hline AFDC Waiver*Target & $\begin{array}{c}0.0341 * * \\
(0.0147)\end{array}$ & $\begin{array}{c}0.0354 \\
(0.0218)\end{array}$ & $\begin{array}{l}0.0880^{*} \\
(0.0437)\end{array}$ & $\begin{array}{c}0.0473 \\
(0.0288)\end{array}$ & $\begin{array}{c}0.0695 * * \\
(0.0335)\end{array}$ & $\begin{array}{c}0.0404 * * * \\
(0.0120)\end{array}$ & $\begin{array}{l}0.0332 * * \\
(0.0126)\end{array}$ & $\begin{array}{c}0.0117 \\
(0.0166)\end{array}$ & $\begin{array}{l}0.0280 * * \\
(0.0134)\end{array}$ & $\begin{array}{l}0.0246 * * \\
(0.0119)\end{array}$ \\
\hline TANF*Target & $\begin{array}{l}0.0179^{*} \\
(0.0098)\end{array}$ & $\begin{array}{c}0.0427 * * * \\
(0.0113)\end{array}$ & $\begin{array}{c}0.0529 * * * \\
(0.0192)\end{array}$ & $\begin{array}{c}0.0268 \\
(0.0215)\end{array}$ & $\begin{array}{c}0.0108 \\
(0.0168)\end{array}$ & $\begin{array}{c}0.0312^{* * * *} \\
(0.0083)\end{array}$ & $\begin{array}{c}0.0318 * * * \\
(0.0068)\end{array}$ & $\begin{array}{c}0.0179 \\
(0.0117)\end{array}$ & $\begin{array}{c}0.0217 * * \\
(0.0103)\end{array}$ & $\begin{array}{l}0.0178^{*} \\
(0.0091)\end{array}$ \\
\hline Observations & 52,359 & 20,800 & 17,477 & 20,906 & 17,411 & 52,835 & 54,225 & 52,473 & 54,458 & 55,265 \\
\hline Sample & \multicolumn{10}{|c|}{$\begin{array}{l}\text { Girls } \\
0 \& 12 \text { and } \leq 17 y\end{array}$} \\
\hline AFDC Waiver & $\begin{array}{c}-0.0239 * * \\
(0.0102)\end{array}$ & $\begin{array}{c}0.0019 \\
(0.0079)\end{array}$ & $\begin{array}{l}-0.0130 \\
(0.0110)\end{array}$ & $\begin{array}{l}-0.0176 \\
(0.0127)\end{array}$ & $\begin{array}{l}-0.0065 \\
(0.0064)\end{array}$ & $\begin{array}{c}0.0175 \\
(0.0186)\end{array}$ & $\begin{array}{c}0.0086 \\
(0.0098)\end{array}$ & $\begin{array}{c}0.0162 \\
(0.0178)\end{array}$ & $\begin{array}{l}-0.0053 \\
(0.0158)\end{array}$ & $\begin{array}{l}0.0095^{*} \\
(0.0051)\end{array}$ \\
\hline TANF & $\begin{array}{c}0.0273 \\
(0.0195)\end{array}$ & $\begin{array}{c}0.0132 \\
(0.0211)\end{array}$ & $\begin{array}{l}-0.0005 \\
(0.0246)\end{array}$ & $\begin{array}{c}0.0218 \\
(0.0254)\end{array}$ & $\begin{array}{l}-0.0330 \\
(0.0206)\end{array}$ & $\begin{array}{l}-0.0214 \\
(0.0263)\end{array}$ & $\begin{array}{l}-0.0047 \\
(0.0156)\end{array}$ & $\begin{array}{l}-0.0190 \\
(0.0243)\end{array}$ & $\begin{array}{l}-0.0249 \\
(0.0187)\end{array}$ & $\begin{array}{l}-0.0128 \\
(0.0093)\end{array}$ \\
\hline AFDC Waiver*Target & $\begin{array}{c}0.0191 \\
(0.0216)\end{array}$ & $\begin{array}{c}0.0014 \\
(0.0117)\end{array}$ & $\begin{array}{c}0.0174 \\
(0.0170)\end{array}$ & $\begin{array}{c}0.0208 \\
(0.0192)\end{array}$ & $\begin{array}{l}-0.0096 \\
(0.0106)\end{array}$ & $\begin{array}{c}0.0089 \\
(0.0150)\end{array}$ & $\begin{array}{c}0.0233^{* * *} \\
(0.0106)\end{array}$ & $\begin{array}{c}0.0091 \\
(0.0146)\end{array}$ & $\begin{array}{c}0.0260 * * \\
(0.0106)\end{array}$ & $\begin{array}{l}-0.0018 \\
(0.0071)\end{array}$ \\
\hline TANF*Target & $\begin{array}{c}0.0164^{* *} \\
(0.0080)\end{array}$ & $\begin{array}{c}0.0089 \\
(0.0099)\end{array}$ & $\begin{array}{c}0.0123 \\
(0.0163)\end{array}$ & $\begin{array}{l}-0.0150 \\
(0.0096)\end{array}$ & $\begin{array}{l}-0.0060 \\
(0.0101)\end{array}$ & $\begin{array}{c}0.0255^{* *} \\
(0.0101)\end{array}$ & $\begin{array}{c}0.0254 * * * \\
(0.0067)\end{array}$ & $\begin{array}{c}0.0141 \\
(0.0090)\end{array}$ & $\begin{array}{c}0.0294 * * * \\
(0.0097)\end{array}$ & $\begin{array}{c}0.0029 \\
(0.0068)\end{array}$ \\
\hline Observations & 66,398 & 26,481 & 22,348 & 26,570 & 22,295 & 66,719 & 68,596 & 66,285 & 68,632 & 69,575 \\
\hline
\end{tabular}

Notes: The target group consists of children with unmarried mothers with a high school education or less; the comparison group consists of children of married mothers with a high school education or less. Coefficients from OLS models are reported. Standard errors are clustered at the state-level and reported in parentheses. Asterisks denote significance as follows: $* * * p$-value $\leq 0.01, * * 0.01<\mathrm{p}$-value $\leq 0.05, * 0.05<\mathrm{p}$-value $\leq 0.10$. All specifications include the following covariates: child's age, grade, and race/ethnicity; the mother's education and marital status; annual state-level measures (unemployment rate, poverty rate, personal income per capita, Earned Income Tax Credit (EITC) rate, refundable EITC, minimum wage, number Medicaid beneficiaries, numbers of National School Lunch and School Breakfast Program participants, and population); and indicators for state, year and month. These results should be compared to the corresponding models in Tables 2 and 3. 


\section{Appendix Table 6}

Effects of Welfare Reform on Youth Behaviors

Controlling for Lagged Economic and Welfare Conditions

MTF 1991-2006

\begin{tabular}{|c|c|c|c|c|c|c|c|c|c|c|}
\hline Outcome & $\begin{array}{l}\text { Skipping } \\
\text { School }\end{array}$ & $\begin{array}{l}\text { Damage } \\
\text { Property }\end{array}$ & Fight & Steal & $\begin{array}{c}\text { Hurt } \\
\text { Someone }\end{array}$ & $\begin{array}{c}\text { Any } \\
\text { Substance } \\
\text { Use } \\
\end{array}$ & Marijuana & Alcohol & Smoking & $\begin{array}{l}\text { Other } \\
\text { Illicit } \\
\text { Drugs } \\
\end{array}$ \\
\hline Sample & \multicolumn{10}{|c|}{$\begin{array}{c}\text { Boys } \\
\text { Grades } 10 \& 12 \text { and } \leq 17 y\end{array}$} \\
\hline Welfare Reform & $\begin{array}{l}-0.0016 \\
(0.0132)\end{array}$ & $\begin{array}{c}-0.0245^{* *} \\
(0.0114)\end{array}$ & $\begin{array}{l}-0.0258^{*} \\
(0.0141)\end{array}$ & $\begin{array}{c}-0.0482 * * * \\
(0.0163)\end{array}$ & $\begin{array}{l}-0.0119 \\
(0.0177)\end{array}$ & $\begin{array}{l}-0.0054 \\
(0.0095)\end{array}$ & $\begin{array}{c}0.0315 \\
(0.0201)\end{array}$ & $\begin{array}{l}-0.0012 \\
(0.0112)\end{array}$ & $\begin{array}{l}-0.0114 \\
(0.0111)\end{array}$ & $\begin{array}{l}-0.0120^{*} \\
(0.0063)\end{array}$ \\
\hline Welfare Reform*Target & $\begin{array}{l}0.0207 * * \\
(0.0094)\end{array}$ & $\begin{array}{c}0.0420 * * * \\
(0.0107)\end{array}$ & $\begin{array}{c}0.0602 * * * \\
(0.0203)\end{array}$ & $\begin{array}{c}0.0300 \\
(0.0207)\end{array}$ & $\begin{array}{l}0.0229 \\
(0.0175)\end{array}$ & $\begin{array}{c}0.0331^{* * *} \\
(0.0078)\end{array}$ & $\begin{array}{c}0.0279^{* * *} \\
(0.0071)\end{array}$ & $\begin{array}{l}0.0170 \\
(0.0116)\end{array}$ & $\begin{array}{l}0.0232 * * \\
(0.0097)\end{array}$ & $\begin{array}{l}0.0193 * * \\
(0.0082)\end{array}$ \\
\hline Observations & 52,359 & 20,800 & 17,477 & 20,906 & 17,411 & 52,835 & 54,225 & 52,473 & 54,458 & 55,265 \\
\hline Sample & \multicolumn{10}{|c|}{$\begin{array}{l}\text { Girls } \\
0 \& 12 \text { and } \leq 17 y\end{array}$} \\
\hline Welfare Reform & $\begin{array}{c}-0.0191 * * \\
(0.0094)\end{array}$ & $\begin{array}{c}0.0038 \\
(0.0094)\end{array}$ & $\begin{array}{l}-0.0114 \\
(0.0115)\end{array}$ & $\begin{array}{l}-0.0071 \\
(0.0135)\end{array}$ & $\begin{array}{l}-0.0025 \\
(0.0073)\end{array}$ & $\begin{array}{c}0.0097 \\
(0.0203)\end{array}$ & $\begin{array}{c}0.0104 \\
(0.0094)\end{array}$ & $\begin{array}{c}0.0058 \\
(0.0192)\end{array}$ & $\begin{array}{l}-0.0074 \\
(0.0153)\end{array}$ & $\begin{array}{c}0.0054 \\
(0.0054)\end{array}$ \\
\hline Welfare Reform*Target & $\begin{array}{l}0.0167^{*} \\
(0.0094)\end{array}$ & 0.0072 & $\begin{array}{l}0.0138 \\
(0.0150)\end{array}$ & $\begin{array}{l}-0.0090 \\
(0.0100)\end{array}$ & -0.0069 & $\begin{array}{l}0.0224 * * \\
(0.0101)\end{array}$ & $\begin{array}{c}0.0244 * * * \\
(0.0065)\end{array}$ & $\begin{array}{l}0.0131 \\
(0.0089)\end{array}$ & $\begin{array}{c}0.0284 * * * \\
(0.0093)\end{array}$ & $\begin{array}{c}0.0019 \\
(0.0063)\end{array}$ \\
\hline Observations & 66,398 & 26,481 & 22,348 & 26,570 & 22,295 & 66,719 & 68,596 & 66,285 & 68,632 & 69,575 \\
\hline
\end{tabular}

Notes: The target group consists of children with unmarried mothers with a high school education or less; the comparison group consists of children of married mothers with a high school education or less. Coefficients from OLS models are reported. Standard errors are clustered at the state-level and reported in parentheses. Asterisks denote significance as follows: $* * * \mathrm{p}$-value $\leq 0.01, * * 0.01<\mathrm{p}$-value $\leq 0.05, * 0.05<\mathrm{p}$-value $\leq 0.10$. All specifications include the following covariates: child's age, grade, and race/ethnicity; the mother's education and marital status; annual state-level measures (unemployment rate, poverty rate, personal income per capita, Earned Income Tax Credit (EITC) rate, refundable EITC, minimum wage, number Medicaid beneficiaries, numbers of National School Lunch and School Breakfast Program participants, and population); and indicators for state, year and month. Models also control for lagged economic /welfare conditions including one, two, and three-year lags of the unemployment rate, poverty rate, state personal income per capita, and welfare caseloads. These results should be compared to the corresponding models in Tables 2 and 3 . 


\section{Appendix Table 7}

\section{Effects of Welfare Reform on Youth Behaviors}

\section{Controlling for State Linear Trends}

MTF 1991-2006

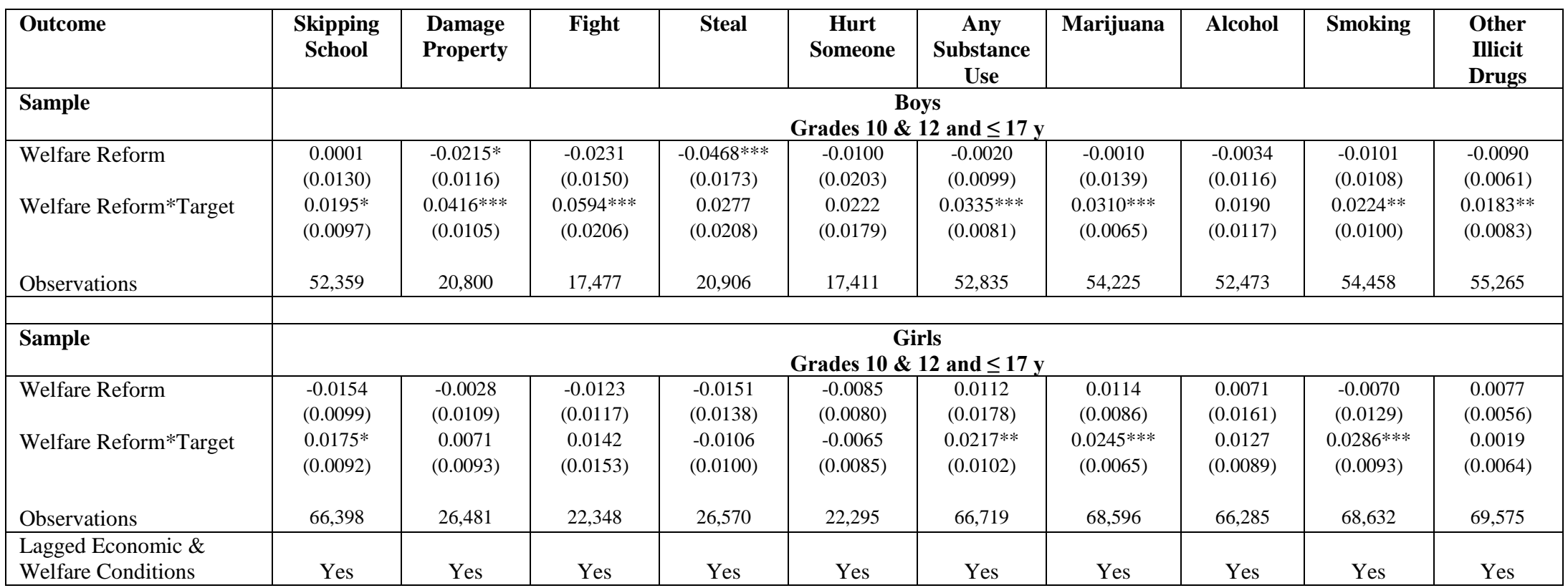

Notes: The target group consists of children with unmarried mothers with a high school education or less; the comparison group consists of children of married mothers with a high school education or less. Coefficients from OLS models are reported. Standard errors are clustered at the state-level and reported in parentheses. Asterisks denote significance as follows: $* * *$ p-value $\leq 0.01, * * 0.01<\mathrm{p}$-value $\leq 0.05, * 0.05<\mathrm{p}$-value $\leq 0.10$ All specifications include the following covariates: child's age, grade, and race/ethnicity; the mother's education and marital status; annual state-level measures (unemployment rate, poverty rate, personal income per capita, Earned Income Tax Credit (EITC) rate, refundable EITC, minimum wage, number Medicaid beneficiaries, numbers of National School Lunch and School Breakfast Program participants, and population); and indicators for state, year and month. Models also control for state-specific linear trends (state dummies interacted with a linear time trend) and lagged economic / welfare conditions including one, two, and three-year lags of the unemployment rate, poverty rate, state personal income per capita, and welfare caseloads. These results should be compared to the corresponding models in Tables 2 and 3. 


\section{Appendix Table 8}

Effects of Welfare Reform on Youth Behaviors

Controlling for School Fixed Effects

MTF 1991-2006

\begin{tabular}{|c|c|c|c|c|c|c|c|c|c|c|}
\hline Outcome & $\begin{array}{l}\text { Skipping } \\
\text { School }\end{array}$ & $\begin{array}{l}\text { Damage } \\
\text { Property }\end{array}$ & Fight & Steal & $\begin{array}{c}\text { Hurt } \\
\text { Someone }\end{array}$ & $\begin{array}{c}\text { Any } \\
\text { Substance } \\
\text { Use } \\
\end{array}$ & Marijuana & Alcohol & Smoking & $\begin{array}{c}\text { Other Illicit } \\
\text { Drugs }\end{array}$ \\
\hline Sample & \multicolumn{10}{|c|}{$\begin{array}{c}\text { Boys } \\
\text { Grades } 10 \& 12 \text { and } \leq 17 y\end{array}$} \\
\hline $\begin{array}{l}\text { Welfare Reform } \\
\text { Welfare Reform*Target }\end{array}$ & $\begin{array}{c}0.0151 \\
(0.0128) \\
0.0202 * * \\
(0.0096)\end{array}$ & $\begin{array}{c}0.0153 \\
(0.0259) \\
0.0428 * * * \\
(0.0126)\end{array}$ & $\begin{array}{l}-0.0210 \\
(0.0324) \\
0.0503 * * \\
(0.0245)\end{array}$ & $\begin{array}{c}0.0002 \\
(0.0378) \\
0.0258 \\
(0.0242)\end{array}$ & $\begin{array}{c}0.0034 \\
(0.0337) \\
0.0200 \\
(0.0225)\end{array}$ & $\begin{array}{c}0.0328^{*} \\
(0.0195) \\
0.0259^{* * *} \\
(0.0084)\end{array}$ & $\begin{array}{c}0.0315 \\
(0.0201) \\
0.0279 * * * \\
(0.0071)\end{array}$ & $\begin{array}{c}0.0169 \\
(0.0208) \\
0.0124 \\
(0.0102)\end{array}$ & $\begin{array}{c}0.0262 \\
(0.0158) \\
0.0171 \\
(0.0110)\end{array}$ & $\begin{array}{l}-0.0048 \\
(0.0149) \\
0.0222 * * \\
(0.0092)\end{array}$ \\
\hline Observations & 52,359 & 20,800 & 17,477 & 20,906 & 17,411 & 52,835 & 54,225 & 52,473 & 54,458 & 55,265 \\
\hline Sample & \multicolumn{10}{|c|}{$\begin{array}{r}\text { Girls } \\
0 \text { \& } 12\end{array}$} \\
\hline $\begin{array}{l}\text { Welfare Reform } \\
\text { Welfare Reform*Target }\end{array}$ & $\begin{array}{l}-0.0153 \\
(0.0153) \\
0.0180^{*} \\
(0.0097)\end{array}$ & $\begin{array}{c}0.0082 \\
(0.0189) \\
0.0076 \\
(0.0097)\end{array}$ & $\begin{array}{c}-0.0196 \\
(0.0221) \\
0.0066 \\
(0.0173)\end{array}$ & $\begin{array}{l}-0.0141 \\
(0.0220) \\
-0.0116 \\
(0.0115)\end{array}$ & $\begin{array}{l}-0.0026 \\
(0.0187) \\
-0.0039 \\
(0.0094)\end{array}$ & $\begin{array}{c}0.0253 \\
(0.0164) \\
0.0185^{*} \\
(0.0097)\end{array}$ & $\begin{array}{c}0.0279 * * \\
(0.0135) \\
0.0251 * * * \\
(0.0062)\end{array}$ & $\begin{array}{c}0.0200 \\
(0.0177) \\
0.0116 \\
(0.0076)\end{array}$ & $\begin{array}{c}0.0069 \\
(0.0140) \\
0.0287 * * * \\
(0.0103)\end{array}$ & $\begin{array}{c}0.0097 \\
(0.0081) \\
0.0043 \\
(0.0061)\end{array}$ \\
\hline Observations & 66,398 & 26,481 & 22,348 & 26,570 & 22,295 & 66,719 & 68,596 & 66,285 & 68,632 & 69,575 \\
\hline $\begin{array}{l}\text { Lagged Economic \& } \\
\text { Welfare Conditions }\end{array}$ & Yes & Yes & Yes & Yes & Yes & Yes & Yes & Yes & Yes & Yes \\
\hline
\end{tabular}

Notes: The target group consists of children with unmarried mothers with a high school education or less; the comparison group consists of children of married mothers with a high school education or less. Coefficients from OLS models are reported. Standard errors are clustered at the state-level and reported in parentheses. Asterisks denote significance as follows: $* * *$ p-value $\leq 0.01, * * 0.01<\mathrm{p}$-value $\leq 0.05, * 0.05<\mathrm{p}$-value $\leq 0.10$. All specifications include the following covariates: child's age, grade, and race/ethnicity; the mother's education and marital status; and annual state-level measures (unemployment rate, poverty rate, personal income per capita,

Earned Income Tax Credit (EITC) rate, refundable EITC, minimum wage, number Medicaid beneficiaries, numbers of National School Lunch and School Breakfast Program participants, and population); and indicators for year, month, and school. Lagged economic / welfare conditions include one, two, and three-year lags of the unemployment rate, poverty rate, state personal income per capita, and welfare caseloads. These results should be compared to the corresponding models in Tables 2 and 3. 


\section{Appendix Table 9 \\ Effects of Welfare Reform on Youth Behaviors \\ Alternate Comparison Group \\ MTF 1991-2006}

\begin{tabular}{|c|c|c|c|c|c|c|c|c|c|c|}
\hline Outcome & $\begin{array}{l}\text { Skipping } \\
\text { School }\end{array}$ & $\begin{array}{l}\text { Damage } \\
\text { Property }\end{array}$ & Fight & Steal & $\begin{array}{c}\text { Hurt } \\
\text { Someone }\end{array}$ & $\begin{array}{c}\text { Any } \\
\text { Substance } \\
\text { Use } \\
\end{array}$ & Marijuana & Alcohol & Smoking & $\begin{array}{l}\text { Other Illicit } \\
\text { Drugs }\end{array}$ \\
\hline Sample & \multicolumn{10}{|c|}{$\begin{array}{c}\text { Boys } \\
\text { Grades } 10 \& 12 \text { and } \leq 17 y \\
\end{array}$} \\
\hline Welfare Reform & $\begin{array}{c}0.0024 \\
(0.0196)\end{array}$ & $\begin{array}{l}-0.0440 \\
(0.0272)\end{array}$ & $\begin{array}{l}-0.0438 \\
(0.0270)\end{array}$ & $\begin{array}{c}-0.1093 * * * \\
(0.0271)\end{array}$ & $\begin{array}{l}-0.0174 \\
(0.0216)\end{array}$ & $\begin{array}{l}-0.0118 \\
(0.0134)\end{array}$ & $\begin{array}{l}0.0232^{*} \\
(0.0129)\end{array}$ & $\begin{array}{l}-0.0206 \\
(0.0191)\end{array}$ & $\begin{array}{l}-0.0076 \\
(0.0113)\end{array}$ & $\begin{array}{c}0.0043 \\
(0.0084)\end{array}$ \\
\hline Welfare Reform*Target & $\begin{array}{c}0.0267 * * \\
(0.0112)\end{array}$ & $\begin{array}{c}0.0503^{* * *} \\
(0.0120)\end{array}$ & $\begin{array}{c}0.0540 * * \\
(0.0220)\end{array}$ & $\begin{array}{c}0.0536 * * \\
(0.0232)\end{array}$ & $\begin{array}{c}0.0339 \\
(0.0223)\end{array}$ & $\begin{array}{c}0.0501 * * * \\
(0.0092)\end{array}$ & $\begin{array}{c}0.0330^{* * *} \\
(0.0087)\end{array}$ & $\begin{array}{c}0.0493 * * * \\
(0.0116)\end{array}$ & $\begin{array}{l}0.0242 * * \\
(0.0097)\end{array}$ & $\begin{array}{r}0.0185 * * \\
(0.0075)\end{array}$ \\
\hline Observations & 22,441 & 8,650 & 7,150 & 8,701 & 7,116 & 22,656 & 23,315 & 22,517 & 23,507 & 23,955 \\
\hline Sample & \multicolumn{10}{|c|}{$\begin{array}{c}\text { Girls } \\
\text { Grades } 10 \& 12 \text { and } \leq 17 y \\
\end{array}$} \\
\hline $\begin{array}{l}\text { Welfare Reform } \\
\text { Welfare Reform*Target }\end{array}$ & $\begin{array}{l}-0.0299 \\
(0.0187) \\
0.0223 * \\
(0.0123)\end{array}$ & $\begin{array}{c}0.0122 \\
(0.0137) \\
0.0011 \\
(0.0112)\end{array}$ & $\begin{array}{l}-0.0039 \\
(0.0168) \\
-0.0067 \\
(0.0179)\end{array}$ & $\begin{array}{c}0.0129 \\
(0.0242) \\
0.0011 \\
(0.0200)\end{array}$ & $\begin{array}{l}-0.0045 \\
(0.0124) \\
-0.0127 \\
(0.0083)\end{array}$ & $\begin{array}{c}-0.0170 \\
(0.0133) \\
0.0313 * * * \\
(0.0091)\end{array}$ & $\begin{array}{c}0.0075 \\
(0.0132) \\
0.0193 * * \\
(0.0087)\end{array}$ & $\begin{array}{c}-0.0153 \\
(0.0149) \\
0.0272 * * * \\
(0.0101)\end{array}$ & $\begin{array}{c}-0.0321 * * \\
(0.0134) \\
0.0339 * * * \\
(0.0123)\end{array}$ & $\begin{array}{c}-0.0077 \\
(0.0094) \\
0.0072 \\
(0.0059)\end{array}$ \\
\hline Observations & 31,448 & 12,081 & 10,035 & 12,117 & 10,020 & 31,689 & 32,665 & 31,554 & 32,708 & 33,259 \\
\hline $\begin{array}{l}\text { Lagged Economic \& } \\
\text { Welfare Conditions }\end{array}$ & Yes & Yes & Yes & Yes & Yes & Yes & Yes & Yes & Yes & Yes \\
\hline
\end{tabular}

Notes: The target group consists of children with unmarried mothers with a high school education or less; the comparison group consists of children of married

mothers with a high school education or less. Coefficients from OLS models are reported. Standard errors are clustered at the state-level and reported in parentheses. Asterisks denote significance as follows: $* * *$ p-value $\leq 0.01, * * 0.01<p$-value $\leq 0.05, * 0.05<p$-value $\leq 0.10$. All specifications include the following covariates: child's age, grade, and race/ethnicity; the mother's education and marital status; annual state-level measures (unemployment rate, poverty rate, personal income per capita, Earned Income Tax Credit (EITC) rate, refundable EITC, minimum wage, number Medicaid beneficiaries, numbers of National School Lunch and School Breakfast Program participants, and population); and indicators for state, year and month. Models also control for lagged economic / welfare conditions including one, two, and three-year lags of the unemployment rate, poverty rate, state personal income per capita, and welfare caseloads. These results should be compared to the corresponding models in Tables 2 and 3. 


\section{Appendix Table 10 \\ Cross-equation Estimates of the Average Effect of Welfare Reform on Youth Behaviors \\ Controlling for Potential Mediators \\ MTF 1991-2006}

\begin{tabular}{|c|c|c|c|c|c|c|}
\hline Sample & \multicolumn{3}{|c|}{ Boys, Grades $10 \& 12$ and $\leq 17 y$} & \multicolumn{3}{|c|}{ Girls, Grades $10 \& 12$ and $\leq 17 y$} \\
\hline Model & 1 & 2 & 3 & 4 & 5 & 6 \\
\hline Outcomes & $\begin{array}{c}\text { Delinquent } \\
\text { Behaviors }\end{array}$ & Substance Use & All Behaviors & $\begin{array}{c}\text { Delinquent } \\
\text { Behaviors }\end{array}$ & Substance Use & All Behaviors \\
\hline $\begin{array}{l}\text { Average DDD Effect: } \\
\text { Welfare Reform*Target } \\
\text { (From Table 4) }\end{array}$ & $\begin{array}{c}0.0818 * * * \\
(0.0254) \\
{[0.001]}\end{array}$ & $\begin{array}{c}0.0574 * * * \\
(0.0143) \\
{[0.000]}\end{array}$ & $\begin{array}{c}0.0709 * * * \\
(0.0159) \\
{[0.000]}\end{array}$ & $\begin{array}{c}0.0112 \\
(0.0179) \\
{[0.531]}\end{array}$ & $\begin{array}{c}0.0419 * * * \\
(0.0110) \\
{[0.000]}\end{array}$ & $\begin{array}{c}0.0248 * * \\
(0.0122) \\
{[0.041]}\end{array}$ \\
\hline $\begin{array}{l}\text { Adding Mediators (A) } \\
\text { Average DDD Effect: } \\
\text { Welfare Reform*Target }\end{array}$ & $\begin{array}{c}0.0836 * * * \\
(0.0300) \\
{[0.005]}\end{array}$ & $\begin{array}{c}0.0491 * * * \\
(0.0180) \\
{[0.006]}\end{array}$ & $\begin{array}{c}0.0683 * * * \\
(0.0190) \\
{[0.000]}\end{array}$ & $\begin{array}{c}0.0055 \\
(0.0211) \\
{[0.795]}\end{array}$ & $\begin{array}{c}0.0331 * * \\
(0.0135) \\
{[0.014]}\end{array}$ & $\begin{array}{c}0.0178 \\
(0.0135) \\
{[0.186]}\end{array}$ \\
\hline $\begin{array}{l}\text { Adding Mediators (B) } \\
\text { Average DDD Effect: } \\
\text { Welfare Reform*Target }\end{array}$ & $\begin{array}{c}0.0843 * * * \\
(0.0284) \\
{[0.003]} \\
\end{array}$ & $\begin{array}{c}0.0498 * * * \\
(0.0177) \\
{[0.005]}\end{array}$ & $\begin{array}{c}0.0690 * * * \\
(0.0177) \\
{[0.000]} \\
\end{array}$ & $\begin{array}{c}0.0079 \\
(0.0212) \\
{[0.709]}\end{array}$ & $\begin{array}{c}0.0365 * * * \\
(0.0129) \\
{[0.005]} \\
\end{array}$ & $\begin{array}{c}0.0206 \\
(0.0132) \\
{[0.142]}\end{array}$ \\
\hline
\end{tabular}

Notes: The target group consists of children with unmarried mothers with a high school education or less; the comparison group consists of children of married mothers with a high school education or less. Delinquent behaviors are skipping school, damaging property, fighting, stealing, and hurting someone. Substance use behaviors are using marijuana, consuming alcohol, smoking, and using illicit drugs. All behaviors include all of the delinquent and substance use behaviors. Models are jointly estimated using a seemingly unrelated regression framework. All outcomes are redefined as standard normal deviates (see text). Estimate of the average effect of welfare reform (average DDD effect) across all noted outcomes is reported, with state-clustered standard errors reported in parentheses and the p-value reported in square brackets. All specifications control for the child's age, grade, and race/ethnicity; the mother's education and marital status; annual state-level measures (unemployment rate, poverty rate, personal income per capita, Earned Income Tax Credit (EITC) rate, refundable EITC, minimum wage, number Medicaid beneficiaries, numbers of National School Lunch and School Breakfast Program participants, and population); and indicators for state, year and month. Mediators (A) include: any work after school, youth is home alone 4+ hours each day, and mother is employed. Mediators (B) further adds hours of work after school and hours youth is home alone. Asterisks denote significance as follows: $* * *$ p-value $\leq 0.01, * * 0.01$ $<$ p-value $\leq 0.05, * 0.05<$ p-value $\leq 0.10$ 